\title{
ROOT CALCRETES AND URANIUM-BEARING SILCRETES AT SEDIMENTARY DISCONTINUITIES IN THE MIOCENE OF THE MADRID BASIN (TOLEDO, SPAIN)
}

\author{
M. ÁNGEleS BUSTILlO, ${ }^{1}$ CHLOÉ Plet, ${ }^{1}$ And ANA M. AlONSO-ZARZA ${ }^{2,3}$ \\ ${ }^{1}$ Departamento de Geología, Museo Nacional de Ciencias Naturales, CSIC, cl José Gutiérrez Abascal no. 2, 28006 Madrid, Spain \\ ${ }^{2}$ Departamento de Petrología y Geoquímica, Facultad de Geológicas, cl José Antonio Novais, Universidad Complutense de Madrid, 28040 Madrid, Spain \\ ${ }^{3}$ Instituto de Geociencias (UCM, CSIC), cl José Antonio Novais, 28040 Madrid, Spain
}

\begin{abstract}
This paper reports a detailed study of the calcrete and silcrete profiles in the Miocene detrital deposits in the western area of Madrid, at the boundary of two main sedimentary units. The aims of this work were to better understand the pedogenic and diagenetic environments in which these profiles formed and to determine the cause(s) of their enrichment in uranium. Calcrete and silcrete duricrusts are characteristic features of closed continental basins in semiarid climates; this paper discusses the significance of duricrusts as indicators of important change in such basins.

The detailed macromorphological, micromorphological, and geochemical study of three duricrust profiles revealed the sequence of pedogenic, vadose, and groundwater processes responsible for their formation. During the first stage of their development, carbonate laminae formed a white "grill-like" structure within the detrital parent materials. The microstructure and macrostructure of the carbonate, which includes alveolar septal structures and needle-fiber calcite, indicates the important role of roots and their associated microorganisms in calcrete formation. Early silicification occurred in the pedogenic-vadose environment affecting the detrital parent material, roots, and calcretes, forming an early silcrete defined by opaline glaebules and silica rhizoliths. The detailed preservation of the cells in the silicified roots denotes the early replacement of root organic matter. The green or green-yellowish fluorescence of the silicified root structures under short-wavelength UV shows their preferential enrichment in uranium. Calcitization and silicification coexisted in the pedogenic vadose environment, leading to several reversible replacements of calcite and silica. Later, the rise of the water table promoted silicification under phreatic conditions, as indicated by the good preservation of the texture of the detrital host rocks and calcretes. Other silcrete textures, such as ovoidal opaline accumulations, intraclasts produced by autobrecchification, and vadose silica cements, indicate later vadose environments, and consequently variations in the water table.

The geochemical features of the calcretes and silcretes (major, minor, and rare earth elements) were inherited from their parent materials. The rare-earth-element patterns of some silcretes show them to have a positive Ce anomaly, suggesting that oxidizing conditions reigned during their formation. The good correlation between silica and uranium suggests that the silica phases acquired uranium through the direct silicification of roots that had fixed uranium from organic matter.

This study shows that calcrete-silcrete duricrusts provide detailed information regarding the processes occurring in semiarid continental basins. In the studied basin, roots played a key role in both the development of the duricrust profiles and their enrichment in uranium. These duricrusts provide important information for understanding the overall stratigraphy of the studied basin and its large-scale sequential evolution.
\end{abstract}

\section{INTRODUCTION}

Calcretes are calcium carbonate accumulations produced in a variety of soils (and paleosols) via pedogenic processes. They also appear as surface sediments where carbonate precipitation takes places in shallow vadose and phreatic meteoric water (Alonso-Zarza and Wright 2010). Aridisols, Vertisols, Mollisols, and Alfisols (Soil Survey Staff 1975) are the most usual soils to contain calcretes (Wright and Tucker 1991), in which they commonly develop in the B or C horizon as illuvial concentrations. In paleosol classifications, calcrete-bearing paleosols are termed Aridisols (Retallack 1993), Calcisols (Mack et al. 1993), or Paleoaridisols (Nettleton et al. 2000).

Silcretes are silica accumulations formed by chemical precipitation as part of pedogenic or nonpedogenic processes at or near the Earth's surface. Pedogenic silcretes may form in a vadose environment through intermittent phases of leaching, infiltration, and illuviation alternating with evaporation (Thiry and Milnes1991). In contrast, the formation of groundwater silcretes is related to silica transport driven by fluctuating water tables or lateral groundwater flows (Thiry et al. 1988; Thiry 1997). Far fewer studies have been published on silcretes than on calcretes, and even fewer on duricrusts, in which calcrete and silcrete interfinger. Silicacarbonate associations form three main types of silcrete-calcrete intergrade duricrust (Nash and Shaw 1998): 1) those with secondary silica occurring within the primary calcareous accumulations, 2) those with secondary carbonate occurring within the primary silica accumulations, and 3) crusts where the precipitation of carbonate and silica appears to have been contemporaneous. The study of the relationships between the textures and structures of calcite and silica minerals (opaline 
phases, moganite, and quartz) throws light on the various processes of silicification and calcification involved in formation of intergrade duricrusts (Bustillo 2010). Interpretations can be complex, since later diagenetic processes mask the primary pedogenic features and because the opaline phases may undergo aging (Thiry and Millot 1987; Lynne et al. 2005), i.e., successive dissolution-precipitation-recrystallization stages that turn opal into moganite and/or quartz, altering the primary textures and mineralogy of these phases.

Calcrete and silcrete duricrusts associate in semiarid, closed continental basins (Watts 1980; Armenteros et al. 1995; Ringrose et al. 2009; PérezJiménez 2010). Such associations are indicators of the prevailing sedimentary regimes, vegetation, and climate, but they also reveal major changes in the position and chemistry of the water table (Watts 1980; Bustillo and Alonso-Zarza 2007). Most studies on calcretes and silcretes have been petrological or have examined their stable isotopes (carbon and oxygen); few have determined their major-element, minor-element, rareearth-element (REE), and uranium concentrations (Ramakrishnan and Tiwari 1998; Ringrose et al. 2009) despite their possible hosting of uranium and gold deposits (McQueen 2006; Liu and Jaireth 2011). Differences in the concentrations of certain elements in the parent material, calcretes, and silcretes can provide clues to the mechanisms and environments of formation of these duricrusts (Kampunzu et al. 2007). Of special importance is the concentration of uranium in siliceous rhizocretions, which suggests a role for vegetation (especially its roots; Dusenkov et al. 1997; Ebbs et al. 1998; Laroche et al. 2005) in the uptake and accumulation of this element (Kabata-Pendias and Pendias 2001).

The present paper reports a detailed petrographic and geochemical study of three calcrete-silcrete duricrusts in the western part of the Madrid Basin. The aims of the study were: 1) to characterize the main petrographic and geochemical signatures of these duricrusts, and to determine whether their geochemical compositions help in their interpretation, 2) to determine the environments and conditions of formation of these terrestrial deposits, and 3) to determine the main processes that contributed to the accumulation of uranium in these duricrusts. The results may help us better understand the sequence of pedogenic-diagenetic (vadose and groundwater) processes that act in distal alluvial-fan areas in semiarid, closed basins. They also indicate the processes that operated in these basins during stages of low sedimentation rates that preceded the major progradations of the alluvial-fan deposits, such as those observed at the boundary between the Lower and Intermediate Units.

\section{GEOLOGICAL SETTING}

The Madrid Basin (Fig 1), which is bounded by reverse and normal faults, is infilled by Cenozoic continental deposits ranging from Paleogene to Pliocene in age. Among these, its Miocene sediments (300 m thick) have been divided into three stratigraphic units, formally defined as the Lower, Intermediate, and Upper Units (Junco and Calvo 1983; AlonsoZarza at al. 2004; and many others) (Fig. 2). The distribution of sedimentary environments and facies shows an irregular concentric pattern, especially in the Lower and Intermediate Units. Coarse alluvial detrital deposits are found close to the margins of the basin, gradually passing into finer clastic sediments (sands and mudstones). In the more central areas of the basin, lacustrine sediments (both carbonates and evaporites) were deposited. Vertical changes can be seen within each Miocene unit, with clastic deposits situated preferentially at the base and carbonates and evaporites at the top. The distinction of the Miocene units from one another is based upon observable lithological differences in vertical sections and the recognition of sedimentary discontinuities (paleokarstic surfaces, thick calcretes, silcretes, erosional and/or minor angular disconformities) (Cañaveras et al. 1996; Rodríguez-Aranda et al. 2002; Pérez-Jiménez 2010). The sedimentary discontinuities are overlain

\section{Lower Miocene Unit (Top)}
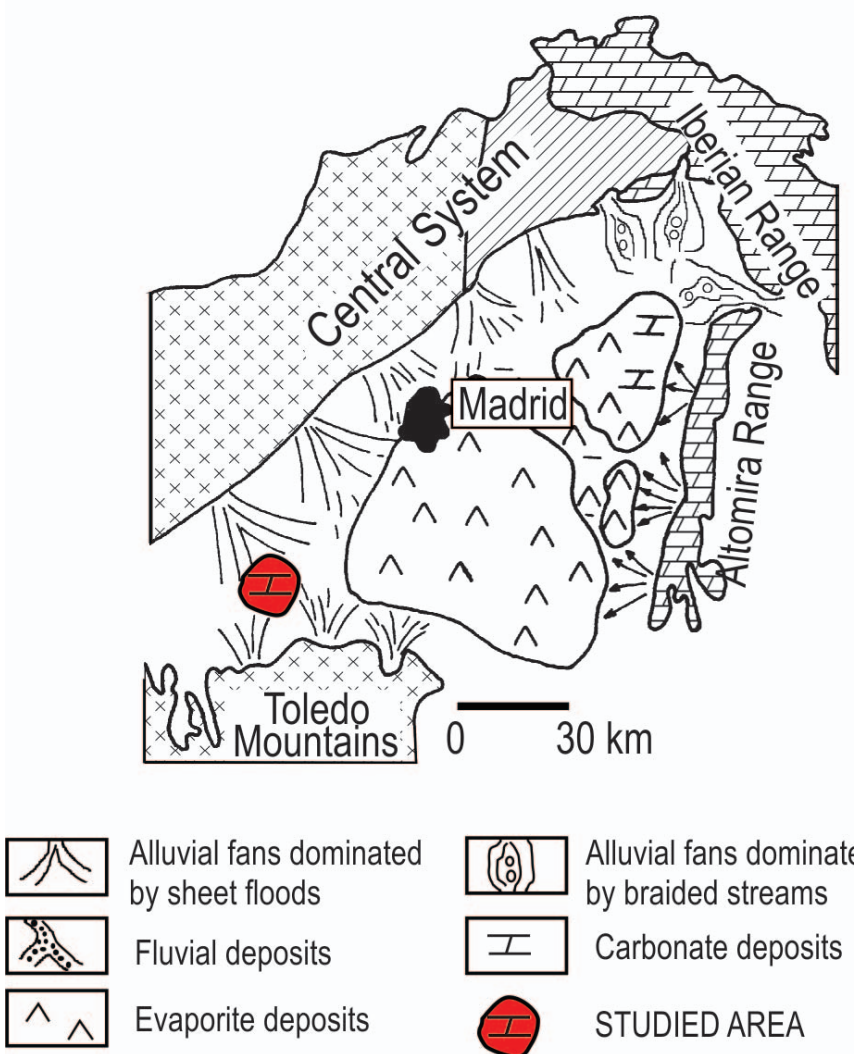

Alluvial fans dominated by sheet floods

Fluvial deposits

Evaporite deposits

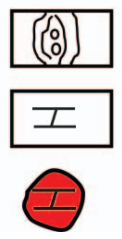

Alluvial fans dominated by braided streams

Carbonate deposits

STUDIED AREA

FIG. 1.-Location of the study area, shown in a paleogeographic sketch of the Madrid Basin at the time of the deposition of the topmost Lower Miocene Unit. The black area is the city of Madrid.

by (usually) clastic deposits of the following unit, a consequence of the progradation of the alluvial deposits coming from the basin margins.

The present study area is located in the western part of the basin (Fig. 1), in the Province of Toledo, near the village of Torrijos. The deposits studied correspond to the top of the Lower Miocene Unit (Fig. 2). These deposits are middle Aragonian in age (López Olmedo et al. 2004); this is corroborated by fossils at the paleontological sites of Torrijos (Aguirre et al. 1982). The Miocene Lower Unit, in the central part of the basin, is composed predominantly of evaporite facies, which grade laterally into reddish-green mudstones containing anhydrite and/or gypsum nodules, and then into coarser clastic materials that were deposited in alluvial environments (Ordóñez et al. 1991). In the western part of the basin, however, the deposits of the Lower Unit consist mainly of arkoses and associated sandy clays supplied by the granitic and high-grade metamorphic rocks of the Central System and the Toledo Mountains. The proximal alluvial fan facies consist of coarse conglomerates with an arkosic matrix; paleosols are very rare. The alluvial facies coalesce distally in this western part of the basin and consist of mudstones with associated calcretes and/or carbonate pond deposits (Alonso-Zarza et al. 2002; López Olmedo et al. 2004). These carbonates are commonly silicified and occur mostly at the top of the Lower Unit, and are the focus of the present work. They are overlain by the detrital alluvial deposits of the Intermediate Miocene Unit.

\section{MATERIALS AND METHODS}

Samples of silcretes, calcretes, and parent materials were studied using conventional mineralogical, petrographic, and geochemical techniques. 


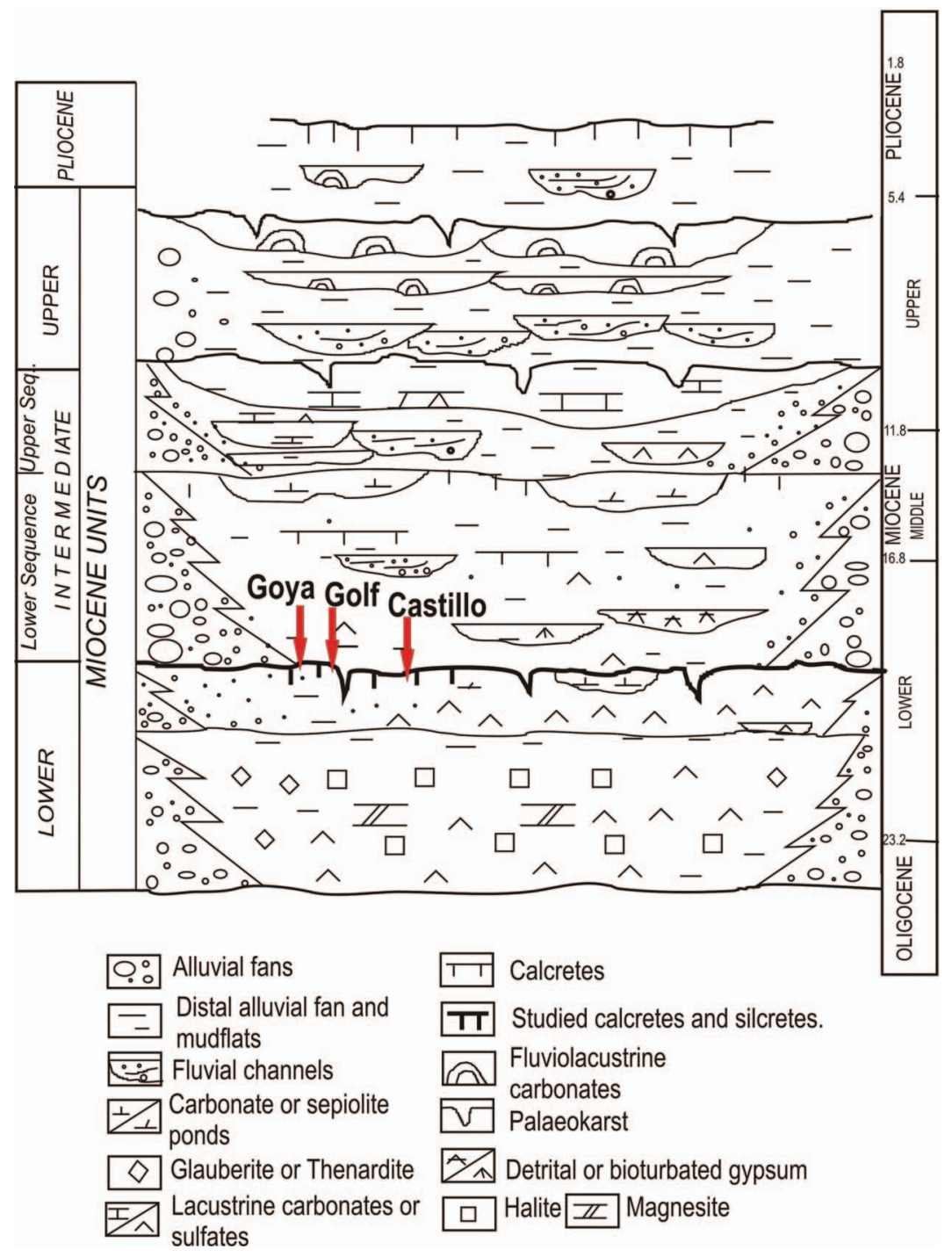

Fig. 2.- Stratigraphy of the study area showing the location of the studied calcretesilcrete profiles at the top of the Lower Miocene Unit. Modified from Alonso-Zarza et al. (2002).

The basic mineralogical and petrographic study involved transmittedlight-microscopy inspection of thin sections under polarized light. Powder X-ray diffraction (XRD) patterns were obtained from pressed powder mounts using a Philips semiautomatic PW 1710 diffractometer with monochromatized $\mathrm{CuK} \alpha$ radiation. Clay mineralogy was determined in oriented, glycol-solvated aggregates heated to $550^{\circ} \mathrm{C}$. Uranium-bearing silica zones were identified under short-wave UV light.

Appropriate areas for analysis by Micro-Raman spectroscopy were selected by optical microscopy. A Thermo Fisher Raman microscope, which has a point-and-shoot Raman capability of $1 \mu \mathrm{m}$ spatial resolution, was used with a $532 \mathrm{~nm}$ laser source. Variations in the moganite/quartz ratio were obtained from the intensity ratios of the main symmetric stretching-bending vibrations of moganite $\left(502 \mathrm{~cm}^{-1}\right)$ and alpha-quartz $\left(465 \mathrm{~cm}^{-1}\right)$, multiplied by $100\left(\mathrm{R}_{\mathrm{M} / \mathrm{Q}}\right)$. This method provides a relative measure of the moganite content in relation to quartz (Bustillo et al. 2012).

Scanning electron microscopy (SEM) observations were made using a FEI INSPECT microscope, working at $30 \mathrm{kv}$ and a distance of $10 \mathrm{~mm}$, operating in high-vacuum mode and using secondary electrons and backscatter detectors. The instrument used was equipped with an Oxford ANALYTICAL-INCA X-ray energy-dispersive system (EDS). Cathodeluminescence SEM (CL-SEM) images and spectra were obtained using a
MONOCL3 Gatan apparatus. The excitation for CL measurements was provided by a $25 \mathrm{kV}$ electron beam. The capability of combining CL with back-scattered electron (BSE) and secondary electron (SE) detection, or with EDS microanalysis, allowed features of the rocks to be correlated with their uranium content.

Precise uranium determinations were obtained by SEM using a FEI QUANTA 200 machine equipped with a wavelength dispersive spectrometry (WDS). The operating conditions were $30 \mathrm{kV}$ with a working distance of $10 \mathrm{~mm}$.

Major, minor, and REE elements were determined by Acme Analytical Laboratories (Vancouver, Canada) using inductively coupled emission spectrometry (ICP-ES) and inductively coupled plasma mass spectrometry (ICP-MS). Loss on ignition (LOI) was determined by weight difference after ignition at $1000^{\circ} \mathrm{C}$ at the same laboratories. The analytical methods and detection limits used can be found at http://www.acmelab.com/.

\section{PROFILES STUDIED}

Three carbonate-silica profiles were studied (termed Goya, Golf, and Castillo), corresponding to the topmost part of the Lower Miocene Unit. The Goya profile is located outside of the village of Val de Santo Domingo, in a recent road cutting made for the Goya Factory. The Golf 


\section{Goya}

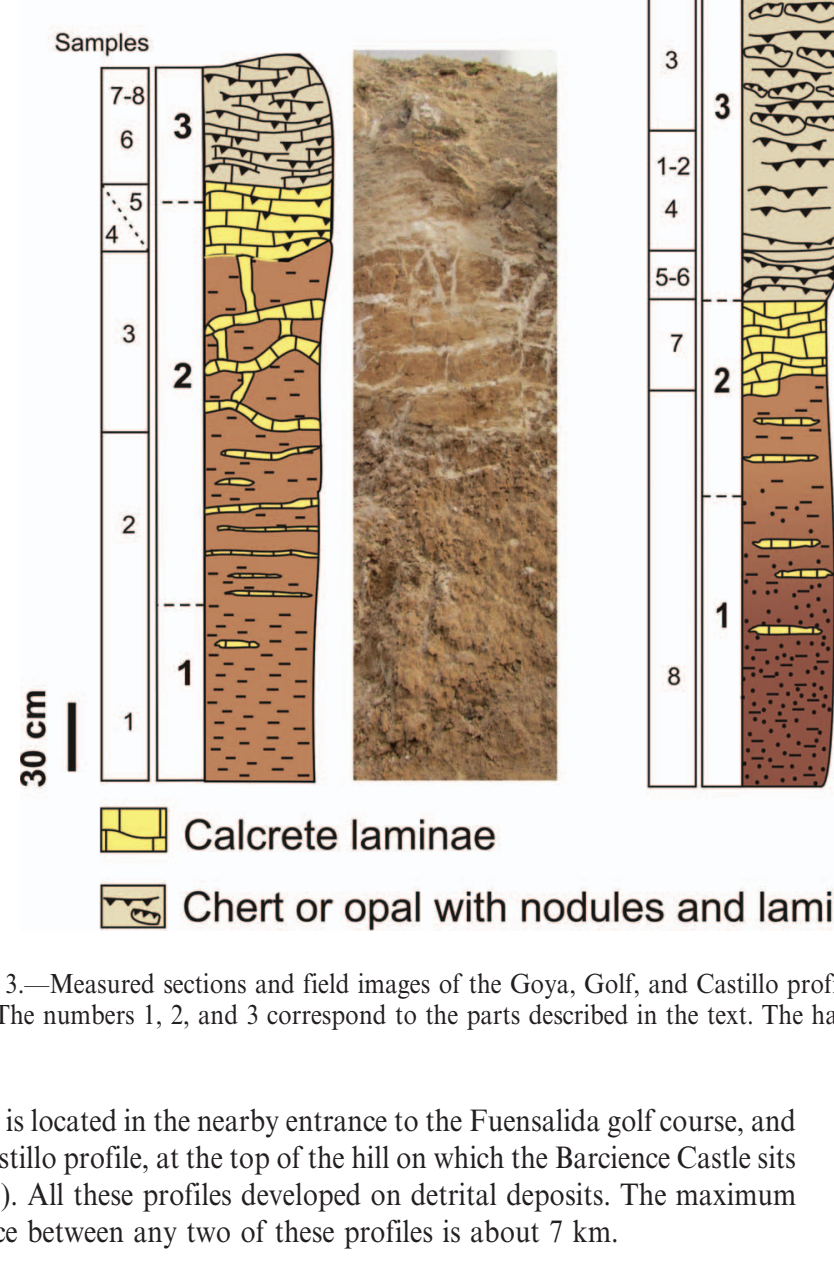

\section{The Goya Profile}

Macromorphology.-This profile is about $2.5 \mathrm{~m}$ thick and is composed of three parts: detrital parent material, calcrete and silcrete duricrusts. The 80-cm-thick parent-material outcrop is a reddish-brown, loose, sandy mudstone, interbedded with sand lenses. The number of these lenses increases toward the top. Carbonates are absent at the base, but they become increasingly common towards the upper part as fine carbonate laminae, giving rise to a gradual transition from the detrital parent material to the calcrete horizon.

The calcrete is composed of three horizons. The lower horizon includes scarce white powdery carbonate nodules and very thin carbonate laminae, slightly inclined with respect to the stratification of the detrital sediments. The intermediate level forms a grill-like horizon about $50 \mathrm{~cm}$ thick. It includes horizontal laminae, $2-4 \mathrm{~cm}$ thick, connected by vertical veins of the same dimensions. The laminae are composed of powdery, soft, whitish carbonate. In the upper horizon, the carbonate laminae are numerous and coalescent.

The top of the profile is harder and shows intense silicification. The mean thickness is $60 \mathrm{~cm}$, varying laterally. This silicified horizon is beige to brown in color with a vitreous luster. At its base it is composed of laminae that correspond to the silicification of the laminar calcrete. Above, the silicification preserves many features of argillaceous sands with partly
Golf

\section{Castillo}

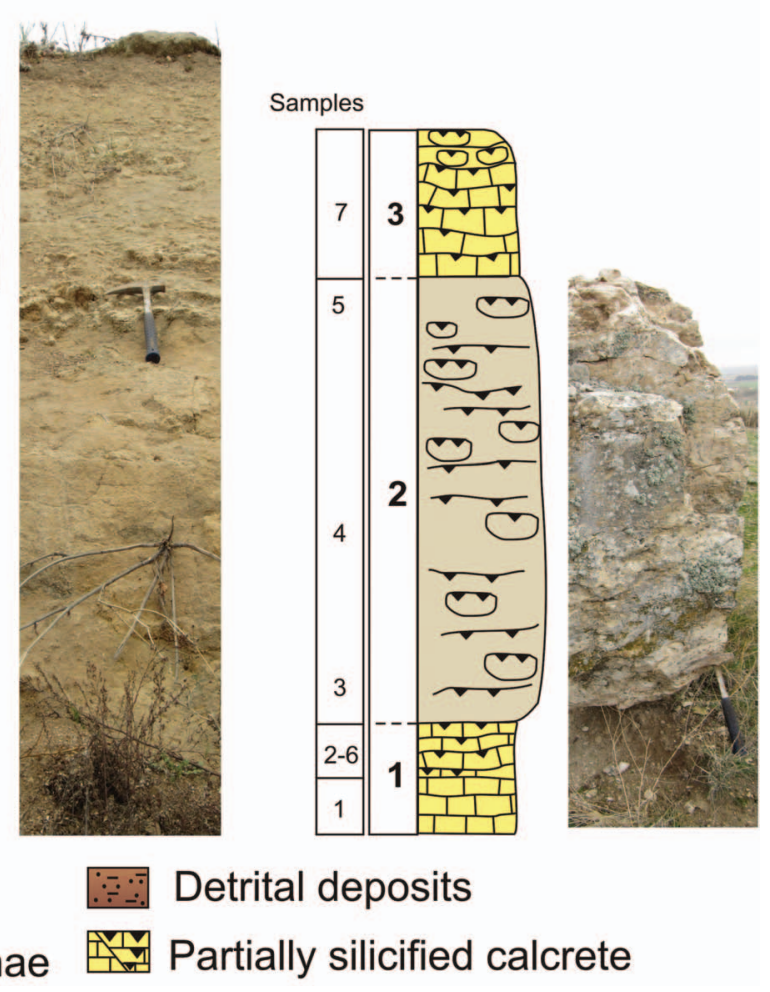

silicified carbonate laminae. Some spherical, ellipsoidal or irregular small silica accumulations $(<1 \mathrm{~cm})$ are visible in the general mass.

Mineralogy and Petrology.-The parent material is composed mainly of detrital grains (quartz $40 \%$, feldspar 30\%, and mica 5-10\%), dioctahedral smectite (around 20\%), and minor amounts of iron oxides. When observed in thin section, samples show irregular, subparallel, flattened patterns of variable orientation corresponding to the smectite.

The carbonate horizons are composed of calcite (around 90\%), minor amounts of quartz $(<10 \%)$, and traces of feldspar, mica, and smectites. The carbonate laminae of the grill-like structures and of the laminar level are composed of a carbonate groundmass and relicts of sandy mudstones. The carbonate groundmass is composed of micritic nodules of differing size $(0.20-2 \mathrm{~mm})$, plus small quartz, feldspars, and mica detrital grains, with the porosity filled by calcite spar cement. The detrital grains have rounded or angular shapes, in some cases are corroded by micrite. These grains are $1 \mathrm{~mm}$ wide and up to $0.8 \mathrm{~mm}$ across. Isolated opaline roots, with the cellular structure preserved, can be seen in the relicts of the detrital parent material and in the carbonate groundmass (Fig. 4A). In addition, local gray patches (up to $0.5 \mathrm{~mm}$ long) composed of needle-fiber calcite crystals (NFC) can be seen (Fig. 4B). According to Verrecchia and Verrecchia (1994), two types of NFC exist: 1) straight needles with a central cavity, known as MA1 rods, and 2) undulating needles, known as MB rods. Both types were seen in the present work. The surface of the needles is coated by microrods (about $100 \mathrm{~nm}$ across and $1 \mu \mathrm{m}$ long) and sparse coccoids (Fig. 4C). The microrods are organized into ovoid masses with a central spherical hole $1-5 \mu \mathrm{m}$ in diameter. Locally, some fungal filaments are visible (100 $\mu \mathrm{m}$ long), their surfaces also covered in 

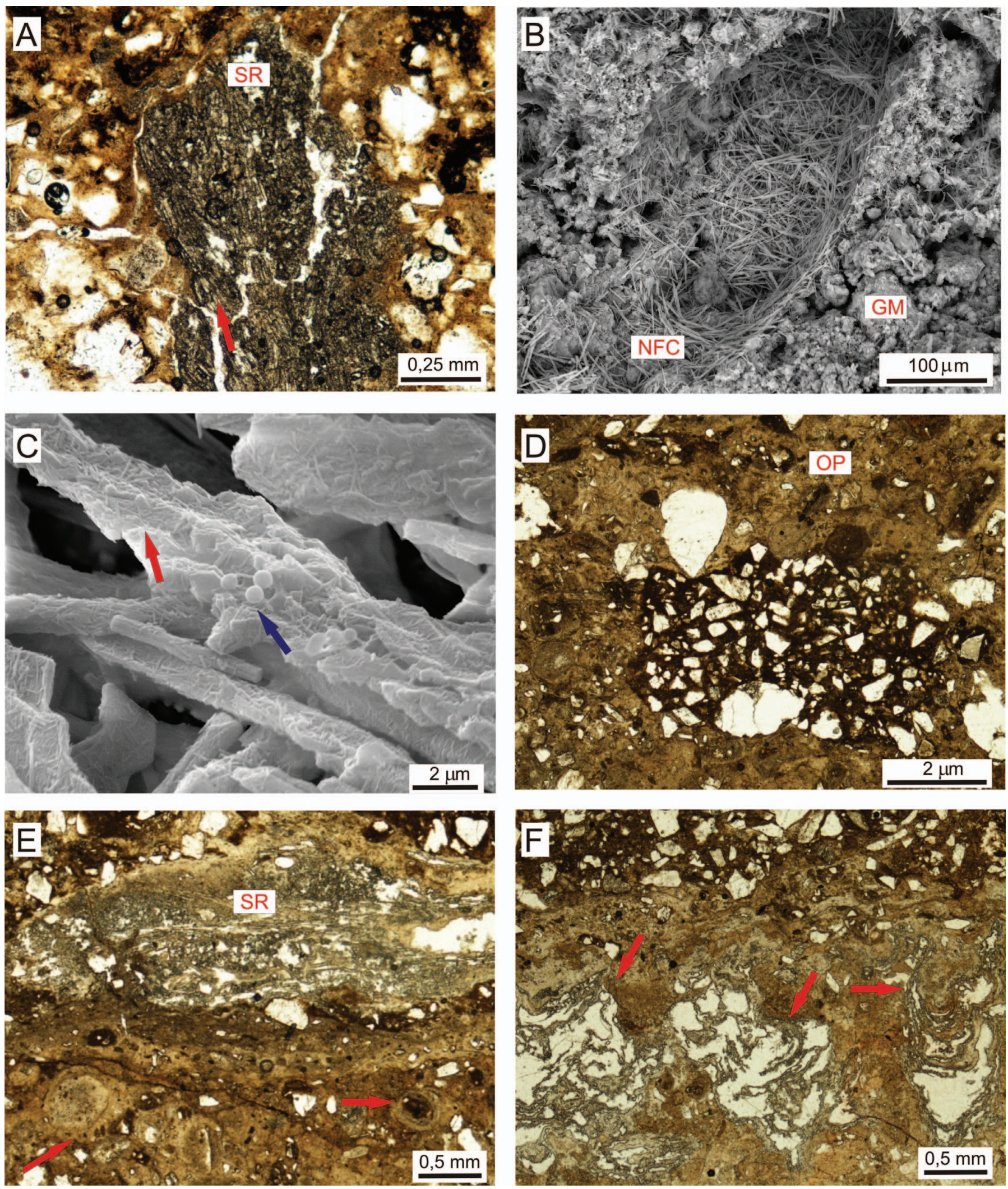

FIG. 4.-Goya profile. Optical microscopy (plane-parallel light) and SEM photographs. The optical-microscope images correspond to thin sections taken perpendicular to the surface of the beds. A) Silica rhizoliths (SR) within detrital host sediments. The root tissues are neatly preserved (red arrow). B) SEM image. Mass of needle-fiber calcite (NFC) crystals within grumelar micrite (GM). C) Detailed view of NFC crystals coated by microrods (red arrow), including some spherical bacterial bodies less than $1 \mu \mathrm{m}$ in diameter (blue arrow). D) Relicts of the detrital parent material (quartz and feldspar grains in a clay matrix) within the opaline mass (OP). E) Horizontal silica rhizoliths (SR) within an opaline mass with ovoids (red arrows). F) Pendant vadose opaline and quartz cements (red arrows) within silica rhizoliths. 


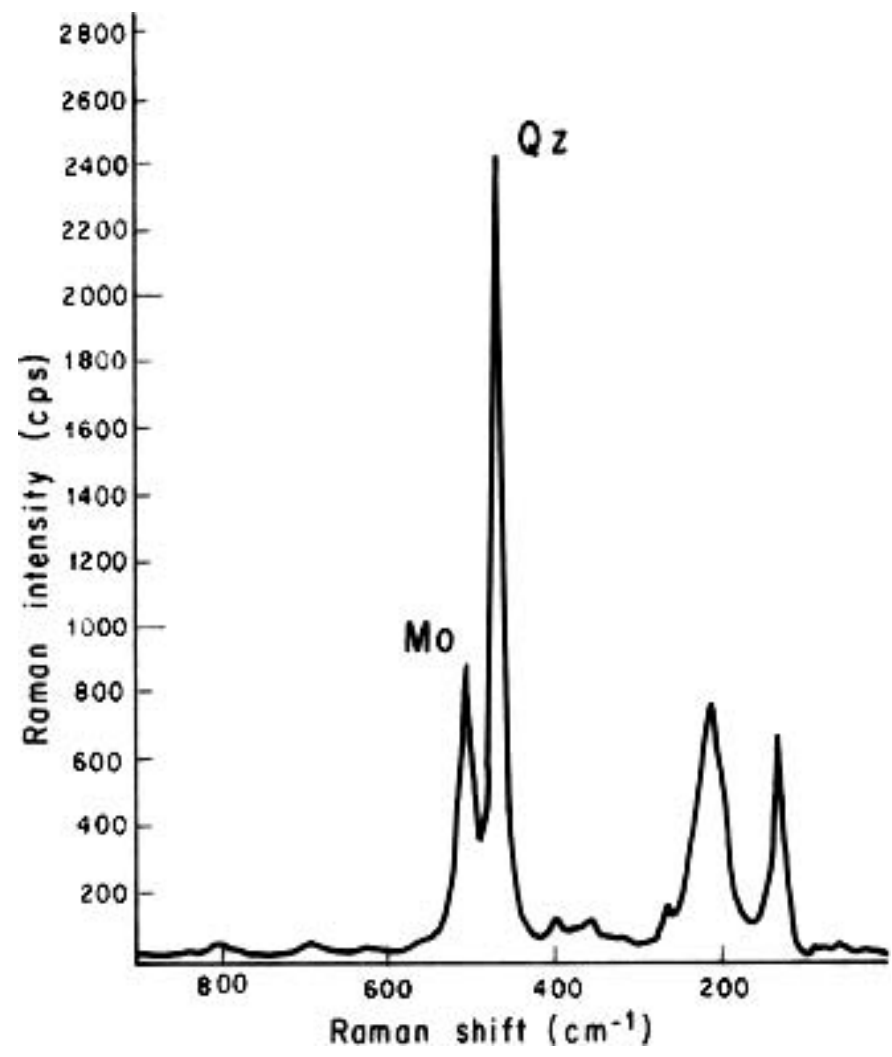

FIG. 5.-Raman spectra obtained from a cryptocrystalline-microcrystalline quartz area of the silcrete, where the moganite peak (Mo) appears next to the quartz peak $(\mathrm{Qz})$.

microrods. EDS analyses of the NFC suggests proportions of carbon attributable to organic matter. The $\mathrm{C} / \mathrm{Ca}$ ratio of an analyzed standard inorganic calcite was around 0.09 , whereas for the studied NFC it was about 2.55 .

The silcretes reproduce, in part, the fabric of the parent material, and include relicts of argillaceous sands, sandy mudstones, and some carbonate laminae. The XRD results show the main silica phases to be opal CT (45 to $60 \%$ ) and quartz (35\%), with small amounts (up to $15 \%$ ) of clays and feldspars. Some opal A may be masked within the opal CT peak. Moganite associated with quartz was identified by micro-Raman analysis revealing a ratio of a moganite $\left(502 \mathrm{~cm}^{-1}\right)$ to alphaquartz $\left(465 \mathrm{~cm}^{-1}\right)\left(\mathrm{R}_{\mathrm{M} / \mathrm{Q}}\right)$ of between 28 and 44 (Fig. 5).

Silicification of the detrital parent materials generated a groundmass containing spherical and ellipsoid opaline accumulations, parent material relicts (Fig. 4D), and silica rhizoliths (Fig. 4E). Locally, the disorganized striated texture of the smectites and many features of the detrital parent materials are preserved. Some siliceous pendant cements are also present (Fig. 4F). Horizontal and vertical rhizoliths appear as fine white silica tubes in the brown opal. Locally they show numerous remains of root cells. In longitudinal section these often appear elongated (about $50 \mu \mathrm{m}$ long by $10 \mu \mathrm{m}$ across) in the direction of the rhizoliths. Some rhizocretions show a structure with: 1) an interior composed of grayish opaline root cells along with cryptocrystalline-to-microcrystalline quartz mosaics and, locally, length-slow chalcedony (generally the cellular structure is better preserved in the opaline part), and 2) a fine outer layer of clear opal with no visible cellular structure or detrital grains.

SEM images show root cells in some cases associated with short NFC crystals (about 6-10 $\mu \mathrm{m}$ long). The small size of the latter may be due to preferential dissolution of their ends. EDS analyses of the silicified roots revealed the presence of organic matter $($ atomic $\mathrm{Si} / \mathrm{C}$ ratio $=1.03$ ).

\section{The Golf Profile}

Macromorphology.-The profile is composed of detrital parent material, calcrete duricrust, and silcrete duricrust. The parent material is composed of reddish-brown sands with very little pedogenic modification; it contains some centimeter-size carbonate nodules. The calcrete $(80 \mathrm{~cm}$ thick) is composed of sparse carbonate laminae with nodules at its base, but its top is composed entirely of amalgamated carbonate laminae. The silcrete has two parts: 1) a lower laminar part (up to $30 \mathrm{~cm}$ thick) showing an alternation of whitish opal and darker, harder crystalline quartz zones about $10 \mathrm{~cm}$ thick, and 2) an upper part (up to $90 \mathrm{~cm}$ thick) composed of a whitish-beige silica groundmass showing nodular shapes.

Mineralogy and Petrology.-The parent material is composed mainly of detrital grains (quartz 70\% and feldspar 20\%), traces of hematite, and smectites.

In the calcrete, the carbonate laminae are composed of up to $95 \%$ calcite, with minor amounts of quartz and feldspar. Under the optical microscope they show a micritic groundmass with sparite cements in cracks (Fig. 6A), and in some places quartz cements filling voids. The scarce detrital grains are highly corroded. The micritic groundmass and the cracks contain many alveolar septal structures (Fig. 6A) and some calcified root cells. Locally there are opal and cryptocrystalline-tomicrocrystalline quartz root structures (Fig. 6B). In general, root cells are better preserved in opal. Some silica rhizoliths appear cracked and fragmented, probably due to dehydration. The cracks are filled with calcite, indicating that calcretization took place. Later, the opaline root structure was transformed into microquartz in the central part of the rhizolith fragments (Fig. 6C). Remains of plant tissue, preserved as opal, can be seen in the outer part.

The silcrete level shows variable degrees of silicification. The lower part is the richest in silica, with $15 \%$ opal and up to $85 \%$ quartz. The moganite, identified by micro-Raman analysis, has $\mathrm{R}_{\mathrm{M} / \mathrm{Q}}$ values of between 30 and 50. Quartz zones show some areas of homogeneous cryptocrystalline-tomicrocrystalline quartz mosaics, and others with mosaics of varied crystal size and length-fast chalcedony. Ovoids and laminations can be observed under crossed-polarized light. The presence of cracks in the cryptocrystallineto-microcrystalline zones, and the close association between the opal and quartz areas, suggest that the quartz is the result of opal recrystallization. Some carbonate micrite remains and partially silicified pendant carbonate cements can be recognized (Fig. 6D). Detrital grains are absent in this level. The upper level of the profile is a partially silicified calcrete (calcite $65 \%$, silica $35 \%$ ) with micrite ellipsoid accumulations (average $1 \mathrm{~mm}$ in diameter) and root structures. Cryptocrystalline-to-microcrystalline quartz mosaics and length-fast chalcedony are the main products of silicification. Opaline patches with detrital grains can be seen in the micrite; these are ellipsoidal, irregular, or angular in shape, and are cut by many micritic veins. Many of these patches show external parts corroded by micrite. In these areas, transformation of the opal into quartz can be seen.

Some silicified roots with preserved cellular structures are composed of cryptocrystalline-to-microcrystalline quartz mosaics and, locally, lengthslow chalcedony. The SEM images show the cellular structure to be preserved in calcite with various degrees of silicification (Fig. 6E) and short NFC crystals in the root trace, as in the Goya profile (Fig. 6F).

\section{The Castillo Profile}

Macromorphology.-This profile is $1.40 \mathrm{~m}$ thick and has three levels. The lower level $(30 \mathrm{~cm}$ thick) is composed of either soft whitish or partially silicified carbonate horizons, and contains relicts of clays and calcified root hairs. The middle level (1 m thick) is massive and intensely silicified (Fig. 3), and of variable color (white, cream, brown, or even 

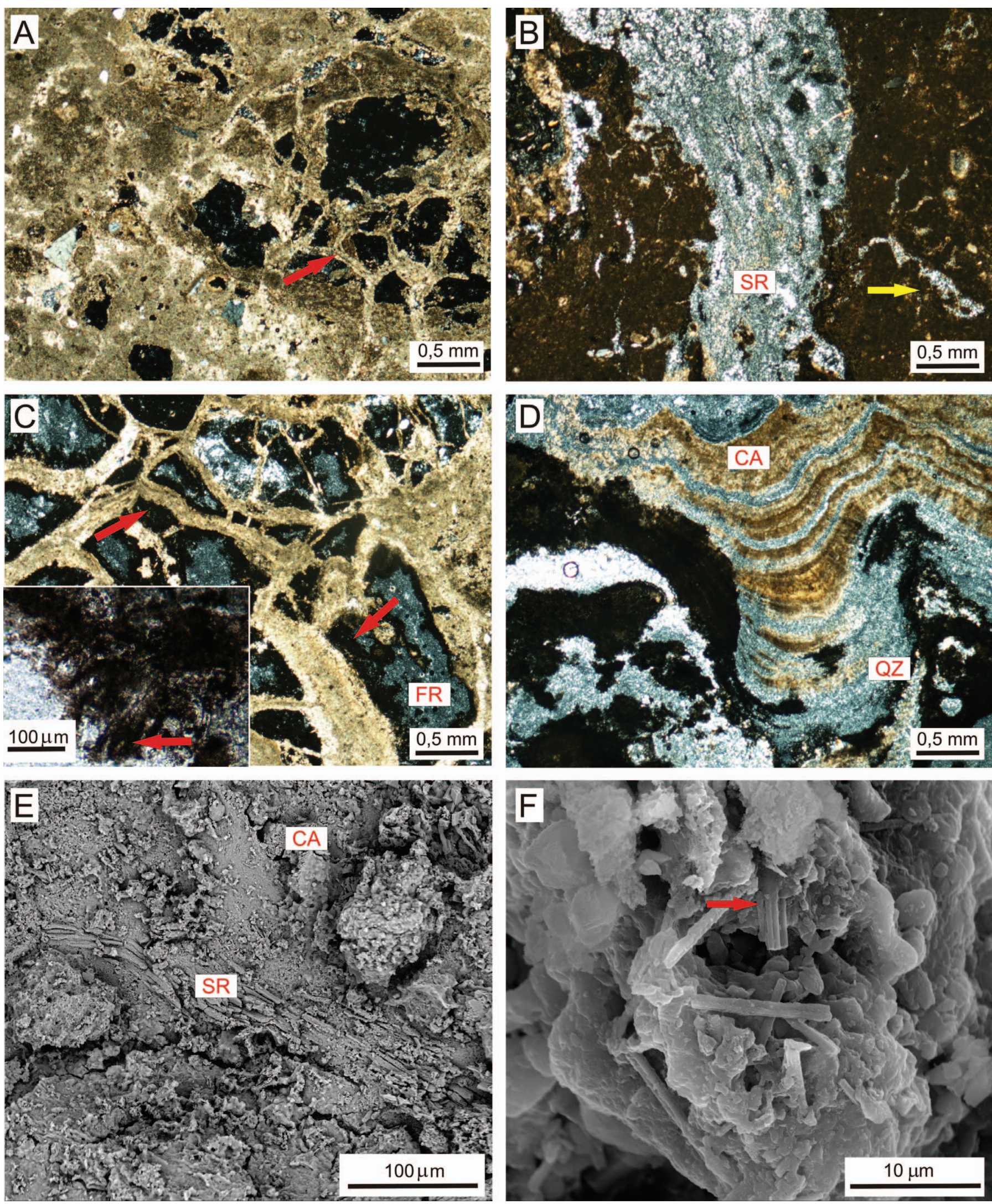
bluish). Spherical, ellipsoidal, and irregular small silica accumulations, intraclasts, and cemented horizontal cracks are common. In some places, this level shows silicified nodular structures. The upper level $(30 \mathrm{~cm}$ thick $)$ is a laminar calcrete composed of 2-cm-thick carbonate laminae with sparse silica nodules.

Mineralogy and Petrology.-The lower horizon is composed mostly of calcite $(>90 \%)$ with scarce detrital grains (quartz and feldspar) and traces of clays. Under optical microscopy its micritic groundmass appears highly porous (largely the porosity left by root networks). Sparite is the most common cement. Locally, argillaceous glaebules with detrital grains are crossed by micrite-filled cracks. The upper part of this lower horizon is silicified (up to $75 \%$ ) and consists of quartz (up to $55 \%$ ) and opal CT (up to 20\%). Opal is found in discontinuous levels with quartz. The quartz occurs in voids (mosaic quartz and length-fast chalcedony cements), but it is sometimes intermixed with the opal in the groundmass as recrystallization textures (aging). Some horizontal levels of opal and cryptocrystallineto-microcrystalline quartz mosaics contain root structures silicified as length-slow chalcedony; no carbonate precursor is visible. Locally, calcified roots can be seen, but their cells are more poorly preserved than in silicified roots. Some of the silica accumulations are broken by cracks filled by micrite, which also etch the opal (Fig. 7A), indicative of a later calcretization stage.

The middle massive level is composed mainly of opal CT (25 to $50 \%$ ), quartz (30 to $70 \%$ ), and relicts of calcite and feldspar. Micro-Raman spectrometry showed moganite to also be abundant $\left(\mathrm{R}_{\mathrm{M} / \mathrm{Q}} 20-90\right.$ depending on the area). The cryptocrystalline-to-microcrystalline quartz zones show the highest $\mathrm{R}_{\mathrm{M} / \mathrm{Q}}$ values.

Thin sections showed this middle level to be composed of an opaline groundmass, either very light in color and poor in detrital grains, or darker (brown or grayish) with more grains. Some areas are richer in micrite containing many rounded or angular detrital grains, in some instances corroded at their edges. Root structures appear as gray-brown opal with some preserved cell walls. The uppermost part of this massive silica level contains no carbonates, but it does contain floating detrital grains. It also includes silicified intraformational sandy mudstone clasts (Fig. 7B). The number of detrital grains in these clasts is larger than in the opaline groundmass.

Quartz cementation varies from microcrystalline mosaics to length-fast chalcedony (a normal systematic organization for silica cements between the walls and centers of voids), the result of decreasing amounts of dissolved silica in the pore water. Locally, the infills of some voids are complex and show a base of silicified laminated micrite overlain by length-fast chalcedony cements. These infillings are texturally similar to those of carbonate pseudomicrokarst (Fig. 7C, D).

SEM images show some cavities to contain thin opaline cements (2$3 \mu \mathrm{m}$ thick) that are very different from the groundmass. These cements are composed of silica microspheres (up to $200 \mathrm{~nm}$ size) and lack carbon (as determined by EDS). The opaline cements are made up of lepispheres with a carbon chemical signal (atomic $\mathrm{Si} / \mathrm{C}$ ratio $=4.9$ ). Some lepispheres, seen individually and under higher magnification, appear to be composed of an assemblage of nanospheres (which might be an association of more elongated shapes). Larger and more homogeneous branching filaments are coated and trapped by these lepispheres (Fig. 7E, F).

The upper level is composed mainly of calcite $(>85 \%)$ with small amounts of quartz $(10 \%)$ and opal $(<5 \%)$. The groundmass is composed of micrite, with cracks filled by sparite but in some cases also by lengthfast chalcedony. Opaline glaebules are interspersed among the micrite. These angular or rounded glaebules are crossed and etched by many micrite veins. While some root networks are observed locally, cell structures are very rare or absent. Some silica vadose cements are also found.

\section{GEOCHEMISTRY}

The geochemical compositions of 23 bulk samples representing all material types were analyzed (Tables 1, 2, and 3 as supplementary material, see Acknowledgments).

\section{Major Elements}

The considerable parent-material variation in $\mathrm{SiO}_{2}(49-74 \%), \mathrm{Al}_{2} \mathrm{O}_{3}$ (9.3-16.1\%), $\mathrm{Fe}_{2} \mathrm{O}_{3}(2.7-5.2 \%)$, and $\mathrm{CaO}(1.32-10.97 \%)$ depends on the amount and composition of the detrital sediment, and on the presence of minor amounts of calcite.

The calcrete $\mathrm{CaO}$ content varies from $35.26-42.74 \%$. The $\mathrm{SiO}_{2}$ content (15.42-27.98\%) correlates with that of $\mathrm{Al}_{2} \mathrm{O}_{3}(1.69-3.78 \%)$, indicating that both are sourced from detrital parent-material components, with minor contributions from silica accumulations. In the silcretes, $\mathrm{SiO}_{2}$ varies between $80.83 \%$ and $97.07 \%$, whereas sil-calcrete intergrades have less $\mathrm{SiO}_{2}(42.20-77.56 \%)$ and more $\mathrm{CaO}(9.89-29.61 \%)$.

In the silcrete and sil-calcrete intergrades, the coefficient of correlation for silica with other major elements is negative $(r<-0.98)$, since $\mathrm{SiO}_{2}$ is the product of a silicification process; it therefore replaces other components. The correlation of $\mathrm{Al}_{2} \mathrm{O}_{3}$ with other major elements (Fig. 8A, e.g., see $\mathrm{Fe}_{2} \mathrm{O}_{3}$ and $\mathrm{Al}_{2} \mathrm{O}_{3}$ ) is overall strong and positive, reflecting the composition of the initial detrital components.

\section{Minor Elements}

With the exception of $\mathrm{U}$ and $\mathrm{Sr}$, the minor-element contents of the detrital parent material (Ba, Be, Co, Cs, Ga, Hf, Nb, Rb, Sn, Ta, Th, V, $\mathrm{W}$, and $\mathrm{Zr}$ ) are higher than those of the duricrust. The correlation matrix indicates a good positive correlation of $\mathrm{Al}_{2} \mathrm{O}_{3}$ (generally $r>0.80$ ) with most minor elements, indicating that the minor elements (except for $\mathrm{U}$ and $\mathrm{Sr}$ ) come from detrital minerals of the parent material.

In the duricrusts, the correlation between $\mathrm{U}$ and $\mathrm{SiO}_{2}$ is good $(0.84<r<0.96)$ (Fig 8B). The $\mathrm{U}$ shows a negative correlation with $\mathrm{Al}_{2} \mathrm{O}_{3}$ (up to -0.82 ) and with $\mathrm{CaO}$ (up to -0.95 ), suggesting that it is associated with the opal and quartz. The good positive correlation of $\mathrm{Sr}$ with $\mathrm{CaO}(0.80<r<0.97)$ (Fig. 8C) is due to the substitution of $\mathrm{Ca}$ by $\mathrm{Sr}$ in the carbonate horizons. In the calcretes, the amount of $\mathrm{Sr}$ varies between 320 and $461 \mathrm{ppm}$.

The content of metals depends on the nature of the rock. While detrital parent material is relatively rich in all metals, these are less common in the

$\leftarrow$

FIG. 6.-Golf profile. Optical microscopy (cross-polarized light) and SEM photographs. The optical-microscope images correspond to thin sections taken perpendicular to the surface of the beds. A) Micritic groundmass with sparite cements. The cracks contain calcified alveolar septal structures (arrows). The black zones are pores. B) Microquartz rhizoliths (SR) within a micritic calcrete with desiccation cracks (yellow arrow). C) Part of a large silica rhizolith cut by a network of cracks infilled with calcite. The red arrows indicate areas where calcite clearly cuts the silica rhizolith. The fragments of the silica root structure (FR) show an external part of the opal; the internal parts have been transformed into microquartz by ageing. The high-magnification image shows the structure of the plant tissue in the external opaline area. D) Partially silicified vadose pendant calcite cements showing residual calcite layers (CA) and quartz (QZ) layers. E) SEM image of silica rhizoliths (SR) within a mass of carbonate crystals (CA). F) SEM image of short NFC within the opaline mass of a rhizolith. 

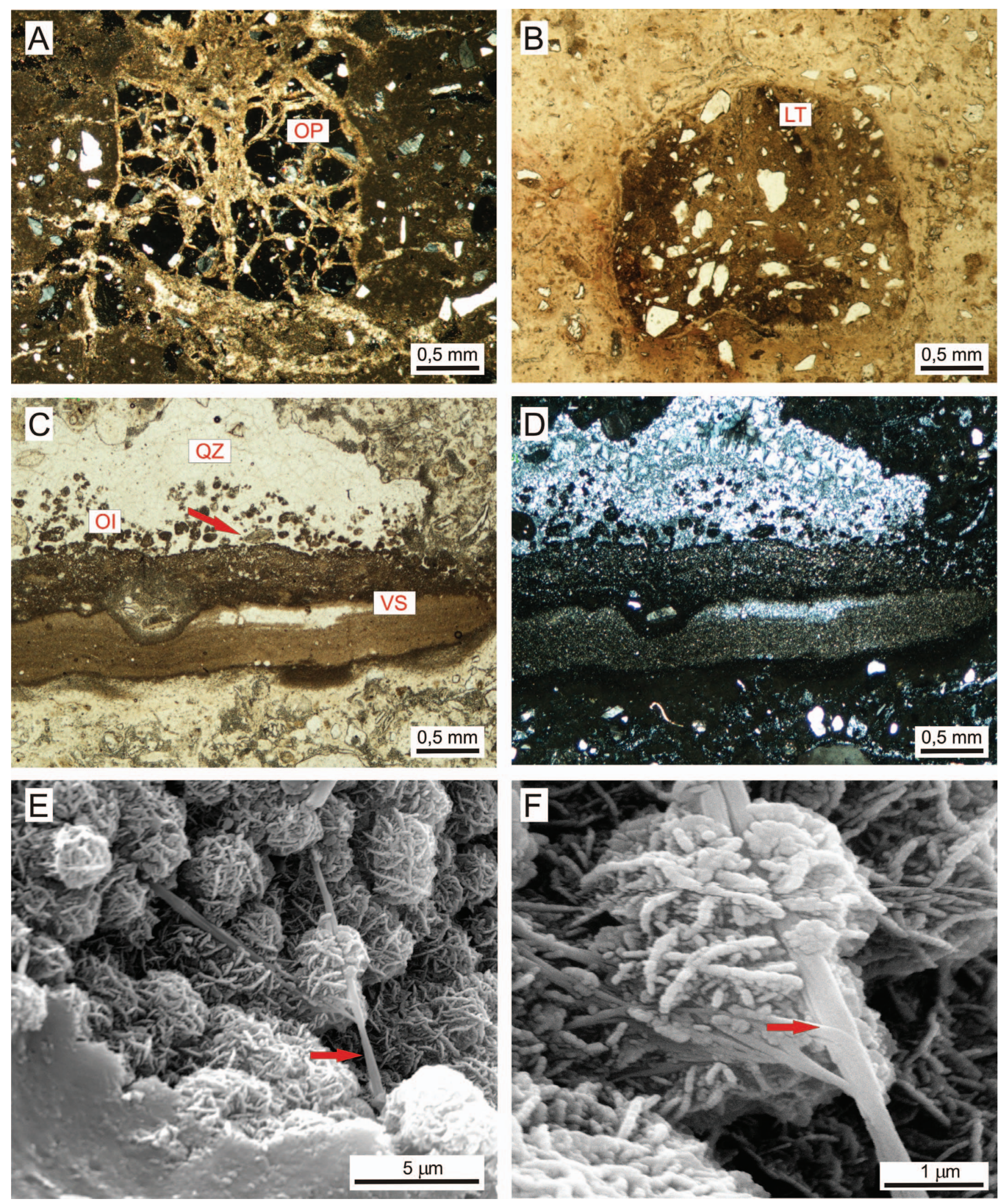
silcretes, with the exception of $\mathrm{Au}(<0.5$ to $87.3 \mathrm{ppm})$. The good correlation $(0.93<r<1)$ of the metal values (with the exception of $\mathrm{Au}$ and $\mathrm{Hf}$ ) with $\mathrm{Al}_{2} \mathrm{O}_{3}$ and $\mathrm{Fe}_{2} \mathrm{O}_{3}$ indicates that they are present in detrital grains and clays within the duricrust. Au does not correlate well with any element, indicating its sporadic detrital origin.

\section{Rare Earth Elements}

The results of REE analyses were normalized using the composition of North American shales (NASC index) (Gromet et al. 1984).

REE contents vary widely, with greater anomalies recorded for the detrital parent-material than for the duricrusts (Fig. 9). In the duricrusts, only weak, negative correlations between $\mathrm{REE}$ and $\mathrm{SiO}_{2}$ and $\mathrm{CaO}$ exist. However, total REE correlates well with $\mathrm{Al}_{2} \mathrm{O}_{3}$ (Fig. 8D), and with $\mathrm{Fe}_{2} \mathrm{O}_{3}(0.80<r<1)$, indicating that the REE are located in relicts of detrital parent materials. In the Castillo profile, the values are lower $(r=0.73)$, possibly because the samples include silcrete lithoclasts of different chemical composition.

In the Goya profile (Fig. 9A), the Eu anomaly of the silcretes is negative, but smaller $\left(\mathrm{Eu} / \mathrm{Eu}^{*}=0.57\right)$ than in the detrital parent material (Eu/Eu* around 0.64$)$. A weak positive anomaly for $\mathrm{Ce}$ is seen in these silcretes, something not seen for the detrital parent material or the silicified roots (see Goya sample 8-clear), which show a flat pattern.

In the Golf profile (Fig. 9B), the calcrete $\mathrm{Ce}$ and $\mathrm{Eu}$ anomalies are negative. Silcrete REE concentrations are low and their patterns nearly flat, with a weak, negative anomaly for $\mathrm{Eu}$ and a weak positive anomaly for Ce.

In the Castillo profile (Fig. 9C), the correlations are not as strong as in the other profiles. Only $\mathrm{Sm}$ and Eu correlate well with $\mathrm{Al}_{2} \mathrm{O}_{3}$ and $\mathrm{Fe}_{2} \mathrm{O}_{3}$ $(0.80<r<0.89)$, possibly because they are located solely in feldspars. The highest REE values were recorded in the duricrust samples (calcretes and some silcretes) with the largest numbers of detrital grains. The Eu negative anomaly of the Castillo profile is very clear, while its $\mathrm{Ce}$ anomaly is weak and variable. The REE content of the intermediate massive silica level is uniformly very small (the curves are nearly flat), with the exception of the Eu negative anomaly (Fig. 8C).

\section{Uranium: Localization and Study}

Under short-wavelength UV, many of the samples show green or green-yellowish fluorescence, indicating the possible presence of uranium. Many areas of fluorescence are associated with vertical or horizontal silicified root structures (Fig. 10A, B). Indeed, in some cases more intense fluorescence is seen at the center of the root structure. In other cases, however, the fluorescence is restricted to fine silicified levels, which in hand samples appear more crystalline (Fig. 10C, D). Geochemical analyses of bulk silcretes and calcrete-silcrete intergrades showed the uranium content to vary from $6.2 \mathrm{ppm}$ to $97.5 \mathrm{ppm}$ (Table 2). The coefficient of correlation of $\mathrm{SiO}_{2}$ with uranium is high $(>0.9)$ suggesting the latter to be located in the silica phases and not in the carbonates. The coefficient of correlation of $\mathrm{CaO}$ with uranium is $-0.84<r<-0.94$. The optical-microscopy observations made indicate the fluorescent areas to be concentrated in zones of cryptocrystalline-to-microcrystalline quartz mosaics. In root structures, the cryptocrystalline-to-microcrystalline quartz displays features corresponding to recrystallization (aging) and to the remains of opal with well-preserved root cell structures. Other fluorescent zones correspond to areas of aging; here the quartz shows striated birefringence, and Micro-Raman analysis indicates relatively large amounts of moganite.

The main Micro-Raman spectroscopy uranium peaks defined by Pointurier and Marie (2010) were not seen in the phases studied. Only a small number of opaline rims showed low-intensity peaks, at 228 $237 \mathrm{~cm}^{-1}, 334-350 \mathrm{~cm}^{-1}$ (broad band), 412-414 $\mathrm{cm}^{-1}$, and 781-784 $\mathrm{cm}^{-1}$. Peaks around $237 \mathrm{~cm}^{-1}$ and around $335 \mathrm{~cm}^{-1}$ have been recorded in some $\mathrm{UO}_{2}$ samples (Manara and Renker 2003). The $412 \mathrm{~cm}^{-1}$ (Piltch et al. 2009; Pointurier and Marie 2010) and the $780 \mathrm{~cm}^{-1}$ peaks have been found in some uranyl chemical compounds (Sarsfield and Helliwell 2004; Frost and Cejka 2009), but for the present samples these peaks appear only weakly, making uranium identification difficult. The CL-SEM studies for uranium yielded more conclusive results. Analyses of the nonfluorescent zones showed spectra with various broad emission bands around 320, 380, 440, 460, and $650 \mathrm{~nm}$ (Fig. 11A) corresponding to opal and quartz (Stevens-Kalceff et al. 1997; Gotze el al. 2001). Other silica zones have two major peaks around $505 \mathrm{~nm}$ and $525 \mathrm{~nm}$, and two minor peaks at 545 and 570 that overlap the silica emission bands (Fig. 11B). These four peaks are attributed to the presence of uranyl ions (Billard and Geipel 2008) in silica minerals. The general shape of the spectra (Fig. 11B) coincides with those of silica gel containing uranium (Cheng 2010). In some cases, silica bands are dominant and can mask the main potential uranium peaks; in other instances the main uranium peaks are so intense that the silica signal is masked (Fig. 10C). CL fluorescence intensity can vary due to the number of uranyl ions, but also because of factors such as particle and pore size or water content in the silica phases (Cheng 2010). In general, spectral analyses show a greater intensity of the major uranium peaks in cryptocrystalline-to-microquartz areas than in opal areas. The CL panchromatic images showed differences of luminescence associated with rock textural features such as ovoid morphologies or groundmass. The SEM with WDS analyses detected very small quantities of uranium (between 0.004 and 0.017 in atomic weight $\%$ ) in some areas of the silicified roots. It is therefore very probable that uranium is dispersed in the opal and quartz, and does not form independent minerals.

\section{DISCUSSION}

\section{Calcretes}

The three profiles studied differ from classic calcrete profiles (Esteban and Klappa 1983). The main difference is the lack of well-developed nodular horizons below the laminar ones; such nodular horizons are commonly described in thick calcrete profiles (Meléndez et al. 2011). Following the classification of Retallack (1988), the soil profiles can be said to be only weakly developed, and it is difficult to classify them according to the morphological classifications of calcic soils (Gile et al. 1965; Machette 1985) or Calcisols (Mack et al. 1993). It is also difficult to determine whether they are part of an A or B horizon of a soil since they occur in different positions within the soil profiles. Mack and James (1992) refer to them as Ak horizons since they occur in the uppermost horizon of a soil and contain carbonate, while Wright et al. (1995) refer to Krh horizons. In two of the profiles studied (Golf and Goya), the horizon below the laminar zone is made up of a framework of horizontal and/or

FIG. 7.-Castillo profile. Optical microscopy and SEM photographs. The optical- microscopy images correspond to thin sections taken perpendicular to the surface of the beds. A) The parent material includes opal angular clasts (OP) that are cut by a dense network of calcite veins (cross-polarized light). B) A silicified intraformational argillaceous sandy clast (LT) in the opaline mass (plane-parallel light). C) The base is a silicified vadose carbonate silt (VS), the middle part corresponds to a new and erosional silicified carbonate vadose layer that also includes opaline intraclasts (OI) such as root tissues (arrow). The upper part it is a quartz cement (QZ) composed mainly of length-fast chalcedony (plane-parallel light). D) Same as Part C (cross-polarized light). E) SEM image of opal lepispheres with organic filaments (red arrow). F) Detailed view of Part E. 
GOYA

(A)
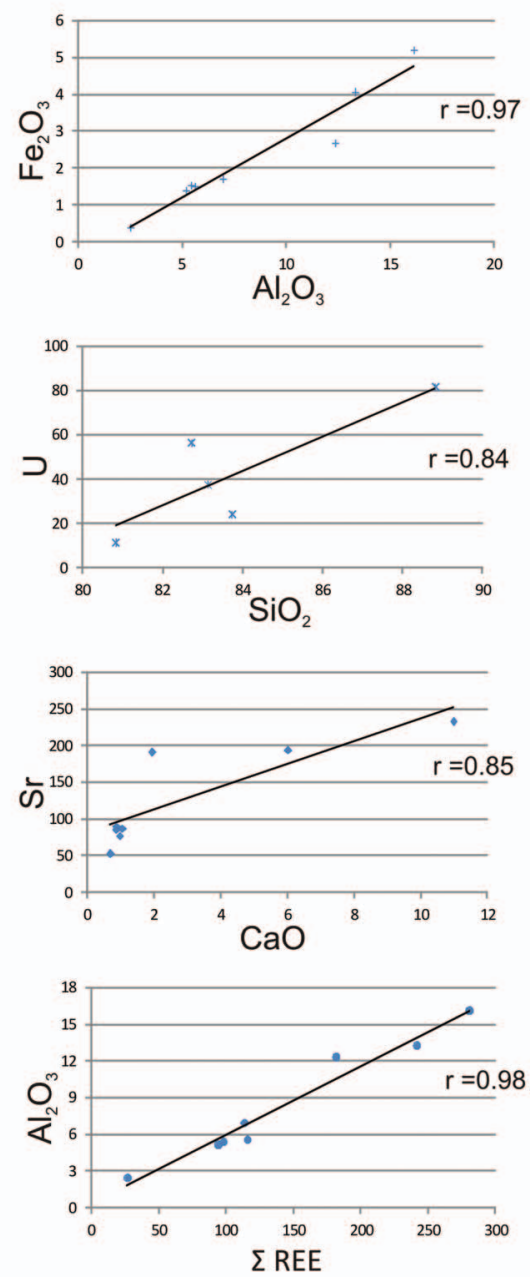

GOLF
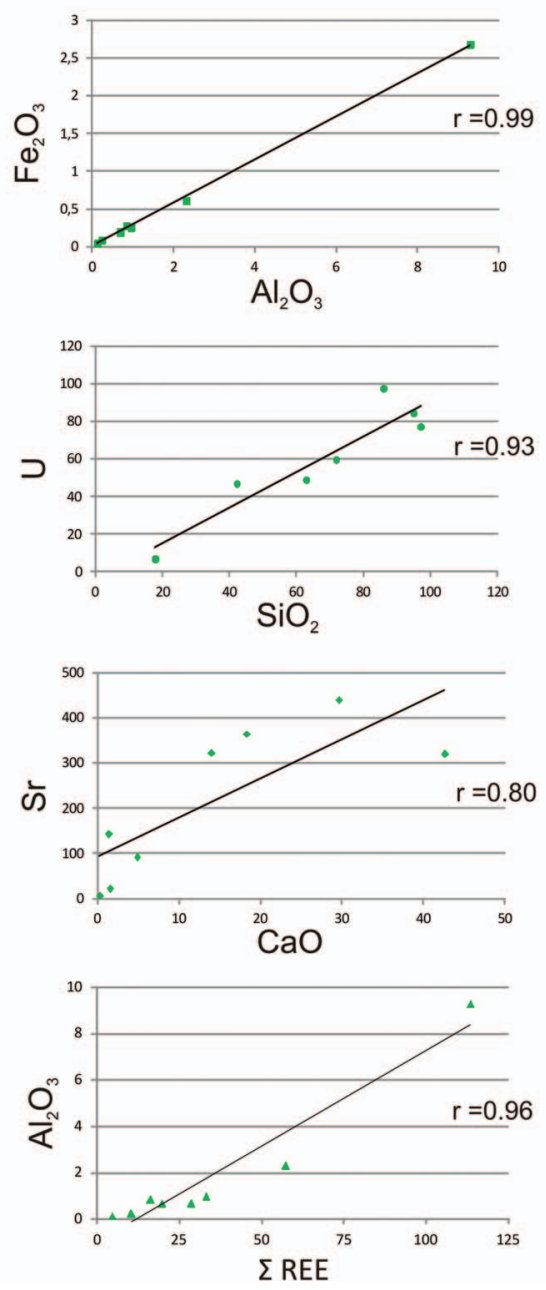

CASTILLO
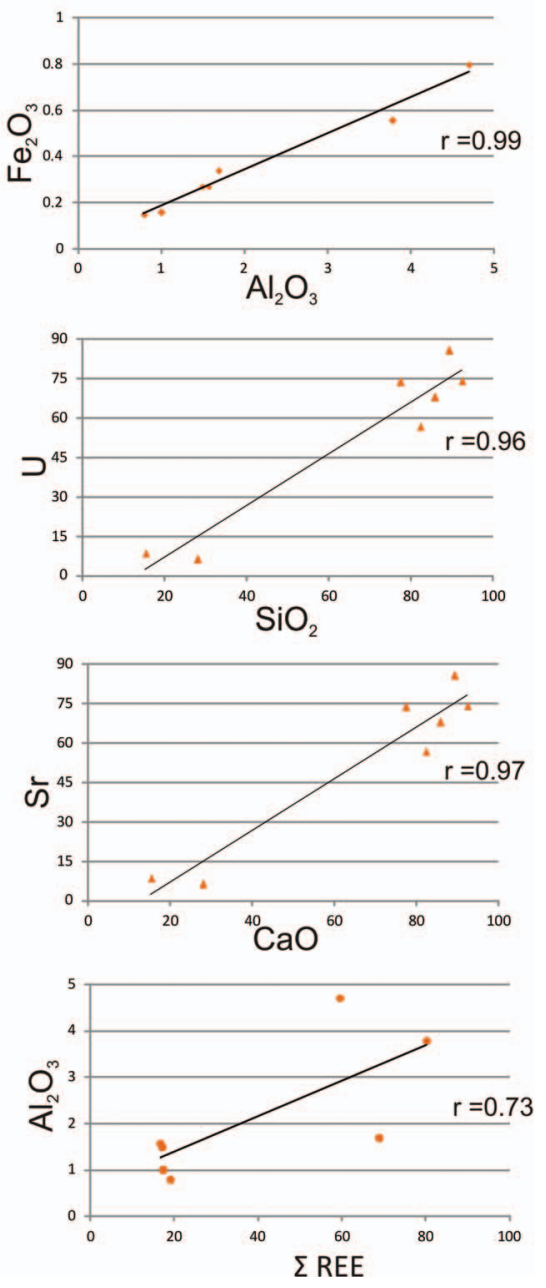

FIG. 8.-Binary diagrams of major-elements, minor-elements and total rare-earth-element concentrations for the Goya, Golf, and Castillo profiles. A) Fe $\mathrm{O}_{3}$ vs. $\mathrm{Al}_{2} \mathrm{O}_{3}$. B) $\mathrm{U}$ vs. $\mathrm{SiO}_{2}$. C) $\mathrm{Sr}$ vs. CaO. D) $\mathrm{Al}_{2} \mathrm{O}_{3}$ vs. $\Sigma$ REE. Major-elements are in $\%$ weight; minor-elements and rare-earth-elements are in ppm.

vertical carbonate laminae intercalated within the parent material (Fig. 3). In the Castillo profile the initial calcrete structure has disappeared due to silicification. The organization of the macrofabric and microfabric of the carbonates is characteristic of incipient calcrete profiles the formation of which is mostly driven by root activity (Alonso-Zarza 1999). Very commonly, calcification of horizontal root mats results in the formation of isolated, thick laminar calcretes, but in other cases thin laminar calcretes are isolated within the parent material (Alonso-Zarza and Wright 2010). The calcification of vertical root systems has also been described (Rossinsky et al. 1992; Alonso Zarza and Jones 2007). In both the Golf and the Goya profiles, the mostly horizontal root systems were connected vertically to form a grill-like framework. All these calcretes can be understood as rootcretes (Jones 1992) or rhizogenic calcretes (Wright et al. 1995).

Evidence of root and associated microorganism activity can be seen in the carbonate laminae. Alveolar septal structures attributed to the calcification of root structures, in association with fungi (Wright 1986), are very common, along with calcified root cells, such as those described by Jaillard et al. (1991) and Kosir (2004). NFC coated with microrods is commonly found in modern and recent carbonate soils (Verrecchia and Verrecchia 1994), which is indicative of either direct fungal biomineralization (MA rods) or of physicochemical mineralization of decayed fungal-sheath organic matter (Verrecchia and Verrecchia 1994; Bajnóczi and Kovács-Kis 2006).

The REE and minor-element contents of the calcretes reflect mainly the composition of the parent material, with the exception of $\mathrm{Sr}$, which is associated with previous carbonate phases. Calcrete enrichment in $\mathrm{Sr}$ is possibly due to the replacement of $\mathrm{Ca}$ by $\mathrm{Sr}$ in carbonates, a consequence of the strong affinity of $\mathrm{Sr}$ for $\mathrm{Ca}$ (both have similar chemical properties) (Morse and Mackenzie 1990; Capo and Chadwick 1999; Dart et al. 2007). This explains the strong correlation between $\mathrm{Sr}$ and $\mathrm{Ca}$ in the studied profiles. Ringrose et al. (2009) suggest that such enrichments may be the product of Sr-enriched plant uptake within the calcrete level. The shape of calcrete REE patterns does not differ greatly from those of the siliciclastic parent material, but the concentration of REE elements is different, indicating a common source for the REE. Relicts of detrital components included in the calcretes are the likely cause of the negative Eu anomaly.

\section{Silcretes}

The silcretes formed by the extensive replacement of detrital parent materials and calcretes. The main characteristics of the observed silcretes are the partial preservation of: 1) the textures, structures, and components 


\section{Goya}

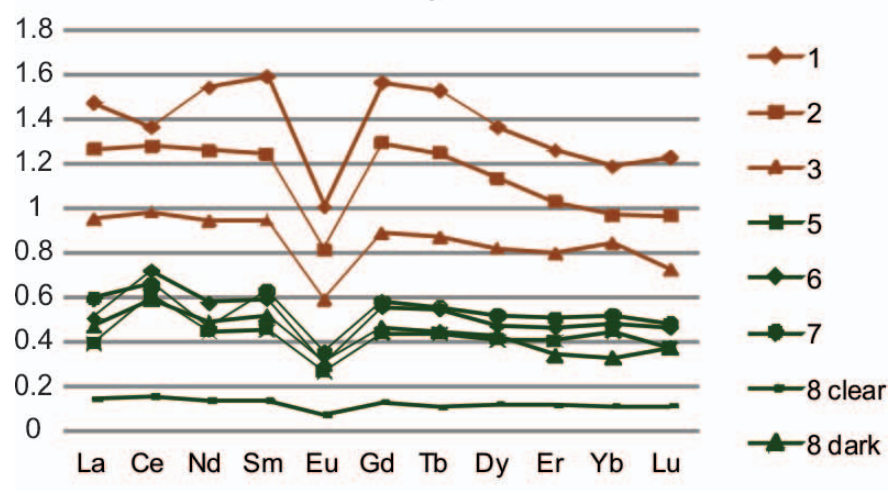

\section{Golf}

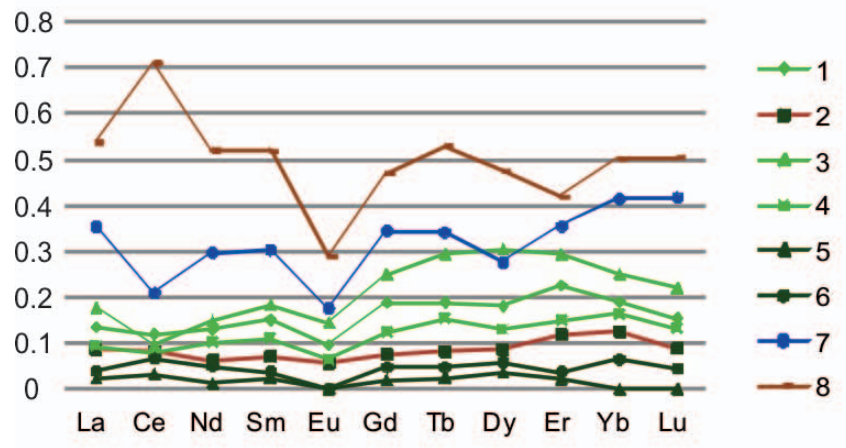

Castillo

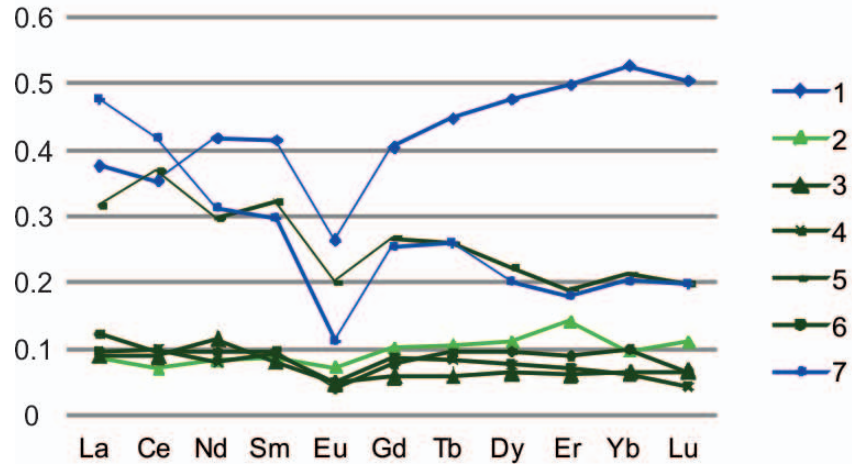

FIG. 9.-NASC-normalized (Gromet el al. 1984) REE plots for samples from the Goya, Golf, and Castillo profiles. Detrital parent materials: Goya-1, 2, and 3 and Golf-8 (brown). Calcretes: Golf-7 and Castillo-1 and 7 (blue). Calc-silcretes: Golf-1, 3, 4, and Castillo-2 (light green). Silcretes: Goya-5, 6, 7, and 8 dark, Golf-2, 5, 6, and Castillo-3, 4, 5, 6 (intense green). Silica rhizolith: Goya-8 clear.

of the detrital parent materials, 2) the macrostructure and microstructure and some components of the calcrete (some detrital grains, relicts of clays, laminar and root structures, glaebules, vadose cements, microkarsts cements, etc.), and 3) the presence of silicified root structures.

The silicification of detrital parent material and the calcretes initially yielded opal. The replacement of calcite by silica (which is very common) is driven mainly by variations in $\mathrm{pH}$. Maliva and Siever (1989) reported three mechanisms for the replacement of carbonates by silica: (1) the production of $\mathrm{CO}_{2}$ by the decomposition of organic matter, or the introduction of $\mathrm{CO}_{2}$ into the water present by biological activity, resulting in a local lowering of the $\mathrm{pH}$ and thus affecting calcite solubility and inducing silica precipitation (Siever 1962; Knoll 1985; among others) (pH values of $<9$ favor the dissolution of calcite and the precipitation of silica whereas higher values induce the opposite, promoting the calcification of silcretes; Nash and Shaw 1998), (2) oxidation of hydrogen sulfide, reducing the $\mathrm{pH}$ at oxic-anoxic boundaries (Clayton 1986), and (3) the dissolution of calcite and the precipitation of silica via the mixing of marine and continental waters (Knauth 1979). Part of the groundwater in the mixing zone can be simultaneously supersaturated in quartz and opal, and undersaturated in calcite. In continental semiarid environments, the same mechanism can occur at the top of the groundwater, where more saline percolating waters mix with less salty groundwater. In the studied duricrusts, mechanisms 1 and 3 may have caused the silicification seen.

The mechanism of silicification of detrital parent material has been studied less extensively than that affecting limestone. However, it involves a progressive loss of $\mathrm{Al}$ in the clay-mineral structures and other aluminum silicates. Any structure remaining after the destruction of the octahedral sheets of the clay minerals must become totally disorganized before any new recrystallization into silica, and this transition could occur only through a local dissolution-recrystallization process (Elssas et al. 2000). The problem is to explain the evacuation of $\mathrm{Al}$ after the replacement of clay minerals and other aluminosilicates. Summerfield (1983) proposes the gradual replacement of clay minerals by silica through the removal of $\mathrm{Al}$ where the $\mathrm{pH}$ is below 4, implying a high rate of organic activity with abundant production of humic acids. However, it would be difficult for such $\mathrm{pH}$ values to exist in the studied environments, except in areas of root decomposition.

The source of silica in groundwater silcretes is sometimes difficult to find. During the Miocene, the Madrid Basin was closed and had an arid or semiarid climate. In semiarid closed basins and near-surface environments, variations in the water table might give rise to complex replacements. Some silica might come from the alteration of siliclastic grains, but much more may come from the formation of calcretes. During calcrete formation, siliciclastic grains are replaced by calcite, and the groundwater, enriched in silica, will migrate across the corresponding alluvial fan towards the lake margins. This source of silica has been recognized for several types of silcrete formed in arid environments (Summerfield 1982; Khalaf 1988; Armenteros et al. 1995). A great deal of silica concentration and precipitation may also occur when water evaporates from plants (Sommer et al. 2006). McCarthy and Ellery (1995) showed the accumulation of silica in the distal reaches of the Okavango Fan (Botswana) to be due to (1) phytoliths mixed with the substrate by illuviation and bioturbation, and (2) the precipitation of finegrained amorphous silica from the groundwater induced by the transpiration of rooted plants, plus increases in salinity.

The aging process promotes the transition opal $\rightarrow$ moganite $\rightarrow$ quartz. Consequently, part of the opal aged to cryptocrystalline-to-microcrystalline quartz mosaics, moganite and small-sized (up to $40 \mu$ ) length-fast chalcedony. Due to the inhibition of aging caused by clay minerals (Bustillo 1982), silcretes that form directly on argillaceous sands contain more opal than quartz; this is not the case for silcretes that replace calcretes. The aging of opal, which is common in surface silcretes (Thiry and Millot 1987), erases part of the original opal textures.

Root cellular structures are better preserved in silica (opal and cryptocrystalline-to-microcrystalline quartz) than in calcite, indicating that some roots were directly silicified without first passing through a carbonate phase. Length-slow chalcedony occurs only in roots, whereas chalcedony is length-fast in the silicified calcrete groundmass. Lengthslow chalcedony, which indicates a basic $\mathrm{pH}$ or evaporitic setting (Folk and Pittman 1971), can be taken as evidence that silicification of root tissue occurred in a microenvironment different from that of calcrete silicification. 

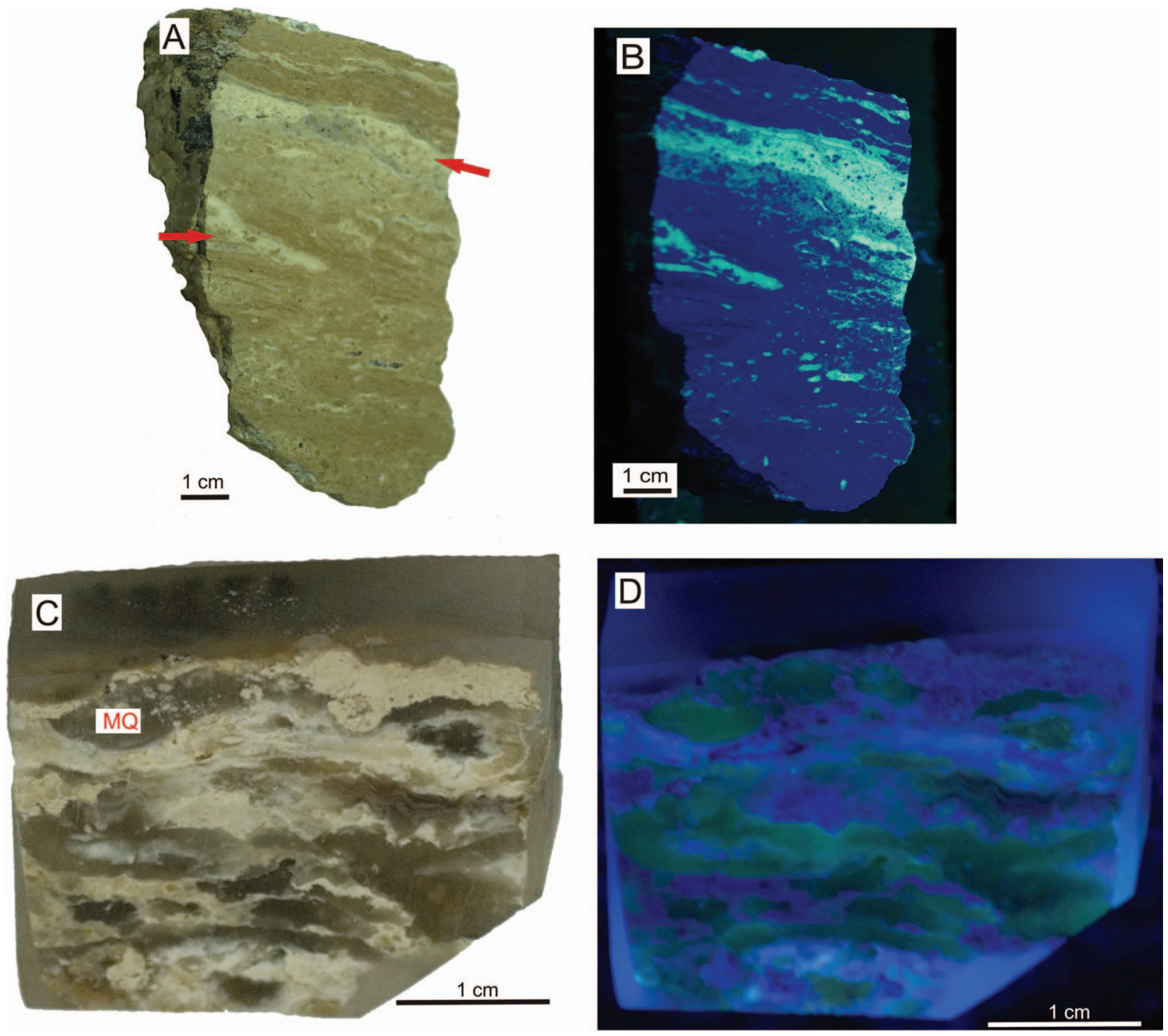

FIG. 10.-A) Hand sample of silcrete from the Goya profile, formed by the silicification of detrital parent material. The brown parts are the silicified detrital deposits; the white parts are mainly opaline rhizocretions (red arrows). B) Image of Part A under short- wavelength UV light. The greener fluorescent areas correspond mainly to rhizocretions. C) Hand sample of silcrete from the Golf profile, formed by the silicification of calcrete. The laminar structure is composed of partially silicified calcrete and cryptocrystalline-microcrystalline quartz zones (MQ). D) Image of PartC under short-wavelength UV light. Zones with green fluorescence are mainly cryptocrystalline-microcrystalline quartz.

Premortem or postmortem silicification of roots is possible. Owen et al. (2008) suggest that the close association of opal with roots indicates that plants contribute to their own silicification through evapotranspiration, which would locally increase the silica concentration. Silica provides mechanical strength, resistance to toxicity, and fluid loss (Epstein 2001). Silica is taken up through the roots as monosilicic acid $\left(\mathrm{H}_{4} \mathrm{SiO}_{4}\right)$ and is commonly precipitated as opal-A. The absorption of silica is likely to continue as long as the silica concentration does not inhibit growth. If concentrations of dissolved silica become very high, the silica and associated salts might have a potentially lethal effect on plant metabolism.

In addition, in pedogenic environments permeated by root networks, pervasive but incomplete decomposition of plant tissue may lead to the post-mortem silicification of root cells (Knoll 1985). Such decomposition impacts the microenvironment, leading to a local increase in $\mathrm{CO}_{2}$ coupled with a reduction in $\mathrm{pH}$.
The studied silcretes are made up of parent material, calcrete relicts, a massive groundmass with spherical, ellipsoidal, or irregular opaline accumulations, and intraclasts. All of these features are common in silicification occurring in surface environments with interplay between phreatic and vadose environments (Bustillo and Alonso-Zarza 2007). Some of the opaline accumulations and intraclasts are replaced by micrite in cracks and/or at the outer edge. Such replacement by calcite indicates that some opal accumulated before or during calcrete development.

With the exception of uranium, these silcretes are deficient in elements found in the relicts of parent materials and calcretes. The REE patterns of the silcretes are nearly flat, but in some cases negative Eu anomalies are related to detrital parent material and calcrete relicts. Ce anomalies are more variable. A positive $\mathrm{Ce}$ anomaly is present in the Goya profile but not in the detrital deposits of the section (Fig. 9). In the Golf profile, small Ce-negative anomalies occur in the REE patterns of some calcretes, while small Ce-positive anomalies occur in those of some 

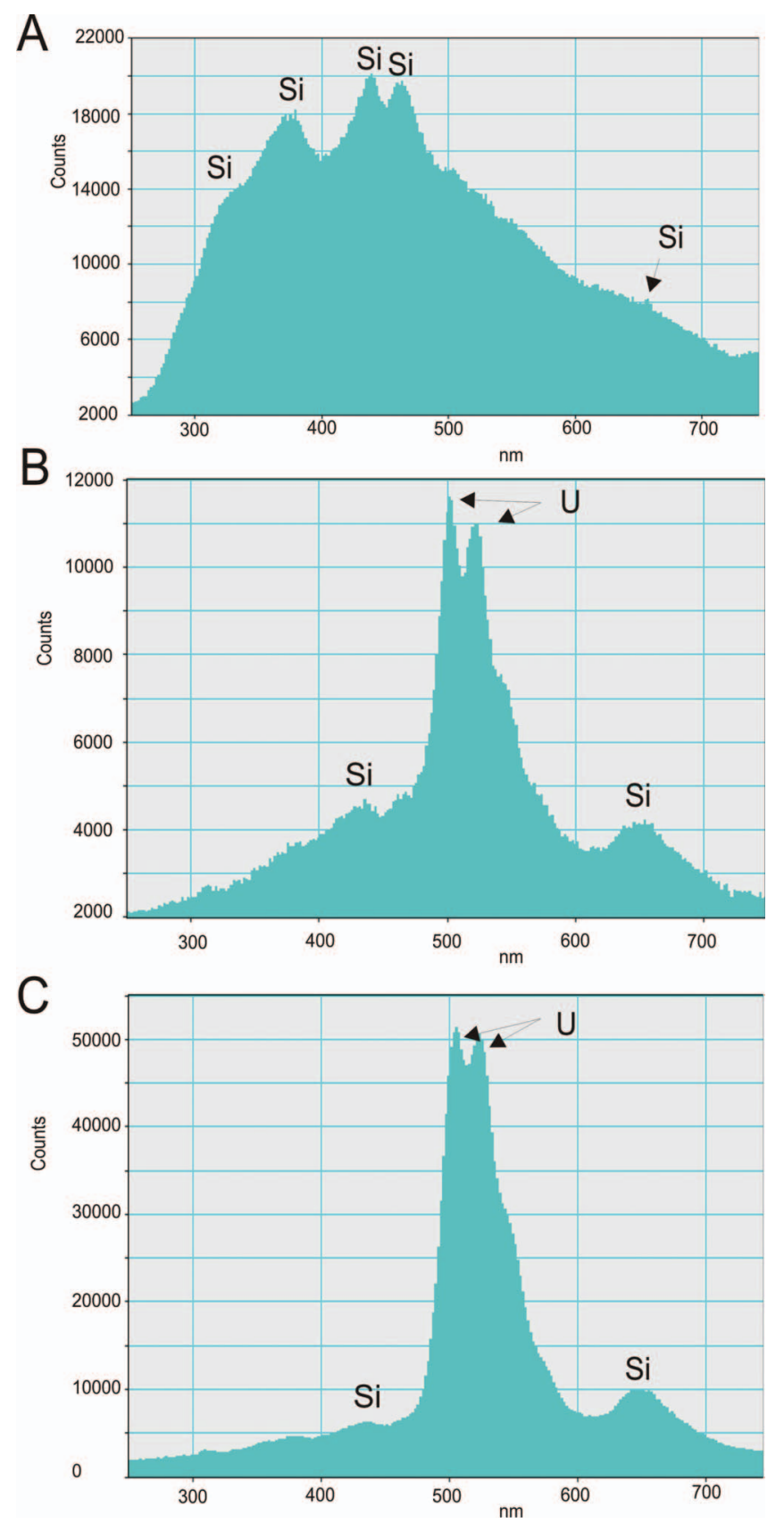

FIG. 11.-Cathode-luminescence SEM spectra. A) Nonfluorescent silica zones with broad emission bands ( $\mathrm{Si}$ ) around 320, 380, 440, and $460 \mathrm{~nm}$, and a weak signal at $650 \mathrm{~nm}$. B) Two major uranium peaks around $505 \mathrm{~nm}$ and $525 \mathrm{~nm}$, and two minor uranium peaks at 545 and 570, overlap the broad emission silica spectra bands ( $\mathrm{Si})$. C) The major uranium peaks are so intense that the silica signal ( $\mathrm{Si})$ is relatively weak.

silcretes (Fig. 9). Ce-positive anomalies are due to a change in valency, from $\mathrm{Ce}^{+3}$ to $\mathrm{Ce}^{+4}$ (immobile form) under oxidizing conditions, and the oxidized $\mathrm{Ce}$ occurring in cerianite $\left(\mathrm{CeO}_{2}\right)$ is accumulated in higher concentrations than other REEs. Positive Ce anomalies tend to form at the tops of weathering profiles in lateritic soils (Braun et al. 1990). Kampunzu et al. (2007) reported duricrusts in the Moshawengh dry valleys of the Kalahari in which calcretes had negative Ce anomalies, while in the cal-silcretes the Ce anomaly was positive, possibly indicating that the silcretes formed from residual solutions after the calcrete precipitated.

\section{Sequences of Processes and Environments}

The processes in the alluvial fans responsible for the formation of the studied profiles include pedogenic, vadose and groundwater processes (Fig. 12).

Pedogenic-Vadose Environment.-Features such as glaebules, nodules, rhizocretions, NFC, and laminar structures indicate that calcrete formed in a pedogenic vadose environment. This is also indicated by the pendant vadose cements.

In the initial stage (stage 1, Fig. 12,) the mineralization of roots by silica and calcite occurred. Later on (stage 2, Fig. 12), the formation of calcite nodules and the progressive calcification of roots accounted for the formation of the thin laminar calcretes. Isolated silica glaebules formed by replacement of the carbonate nodules and laminae, and of the detrital parent material. New silica rhizoliths may also have formed at this stage. Both types of silica accumulation (rhizoliths and glaebules) would lead to the formation of a pedogenic silcrete (Dixon and McLaren 2009). The micrite corrosion of opaline glaebules and the pendant vadose cements indicate a new stage of calcretization (stage 3 , Fig. 12).

Phreatic Environment.-The calcretes and incipient silcretes underwent intense silicification to generate the laterally continuous thick layers and lenticular silica levels. This groundwater silicification affected the detrital rocks of the alluvial fans, the calcretes forming therein (stage 4, Fig. 12), and also the incipient pedogenic silcrete (silicified roots and sparse silica glaebules), reproducing the features of the host rocks, as seen in many groundwater silcretes (Thiry and Ribet 1999; Nash et al. 2004). The groundwater must have contained and transported large amounts of dissolved silica. According to Nash and Ullyott (2007), silicification occurs at the water table, or near groundwater outflow zones, with watertable fluctuations exerting a strong control over silicification. Within the groundwater fluctuation zone, variations in $\mathrm{pH}$ due to recharge caused by meteoric water percolating through the soil capillary zone, plus surface evaporation, would have favored opal precipitation (Arakel et al. 1989). During dry periods a lowering of the water table would have led to the localization of silicified layers and lenticular levels in a vadose environment. New silica textures (spherical or ellipsoidal opaline accumulations, intraclasts produced by autobrecchification, etc.), and vadose silica cements formed, highlighting the interplay between phreatic and vadose environments (stage 5, Fig. 12).

The studied calcrete-silcrete intergrades were favored by a period of very reduced or absent sedimentation in the basin that allowed pedogenic and diagenetic (vadose and phreatic) modification of the primary detrital sediments. It is not easy to say how long this period lasted, but it was probably some hundreds of thousands of years (Bustillo 2010). The landscape was probably very stable over this period.

All the features and processes described herein are linked to a sedimentary discontinuity recognized in most of the Madrid Basin. This discontinuity is the boundary between the Lower and Intermediate Miocene Units (Fig. 2). In the eastern and southern areas of the basin, a large paleokarst developed on evaporite deposits, whereas in the northeastern and western areas, thick palustrine deposits, calcretes, and silcretes record the discontinuity. In short, these duricrusts and their integrades can also be used as indicators of significant sedimentary discontinuities in continental basins.

The Concentration of Uranium.-The detrital siliciclastic strata of alluvial fans are permeable. In the present basin, groundwater circulating through the 


\section{PEDOGENIC-VADOSE ENVIRONMENT}

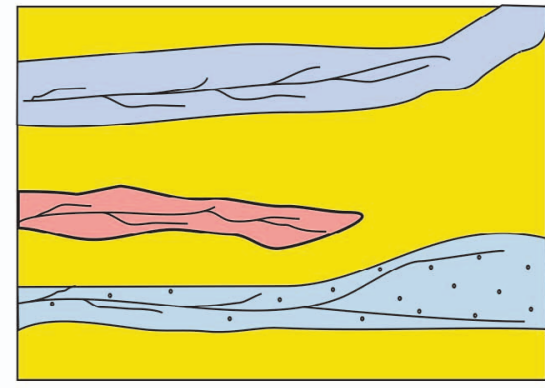

1. Root mineralization: silica and carbonate

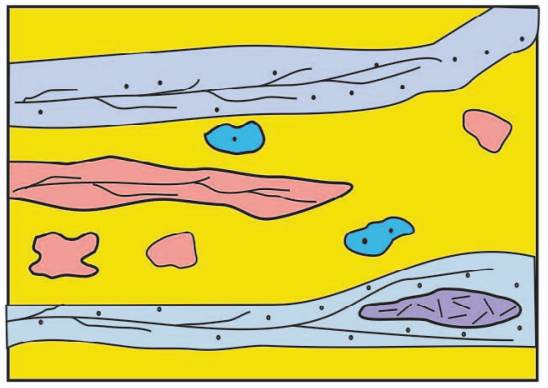

2. Root mineralization, silica glaebules and carbonate nodules

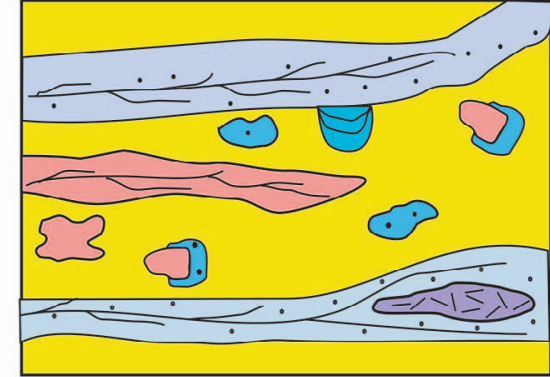

3. Vadose carbonate cements and corrosion of silica by carbonate

\section{PHREATIC-VADOSE ENVIRONMENT}

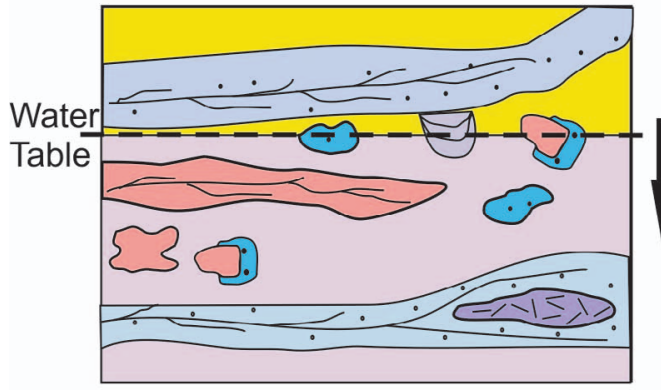

4. Groundwater silicification

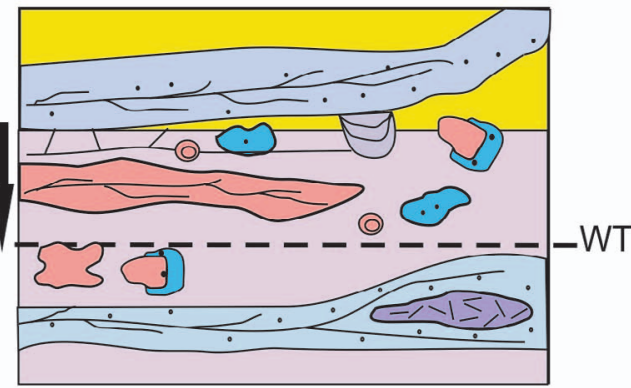

5. Vadose silica transformations
Parent detrital rock

Micrite

Carbonate roots

Silica roots

Carbonate nodules

Needle-Fiber Calcite

Calcite vadose cements

Silicified vadose cements

Silica glaebules

Silica ovoids

Silica groundmass

Silica intraclasts

FIG. 12.- Successive stages in the formation of the calcrete and silcrete duricrusts.

sediments dissolved uranium sourced from the oxidation of detrital uraninite and thorite from cracks in dikes of the Berrocal granitic system (Central Spain) (Gómez et al. 1996). In the initial stages, dissolved uranyl ions possibly accumulated in the roots of living plants, as is seen in some plant species that inhabit arid regions (Kabata-Pendias and Pendias 2001; Luna Porres et al. 2011). The absorption of uranium by roots - probably the result of positively charged uranium ions being attracted to the negatively charged root surface-depends on the initial concentration of the element, the $\mathrm{pH}$, and the duration of contact (Shawky et al. 2005). When available in a solution of oxidizing water, uranium is fixed by local redox reactions in roots.

During early silicification, roots are efficient silica traps due to the presence of organic matter. Uranium taken up by the root would have been incorporated into the opal that formed during the replacement of the root structures. The ability of opal to concentrate uranium is widely referred to in the literature. In colloidal silica, the Si-O- surface termination is a strong Lewis base that forms a stable bond with strong Lewis acids such as $\left(\mathrm{UO}_{2}\right)^{2+}$. This allows $\left(\mathrm{UO}_{2}\right)^{2+}$ to form a strong complex with Si-O polymers (Schindler et al. 2010). An increase in evaporation during the precipitation of opal would favor the incorporation of uranium into the opal structure (Cheng 2010). The recrystallization of opal to quartz (aging) liberates uranium, which would have accumulated on the surface of cryptocrystalline-microcrystalline quartz. The aging and renewed mobilization of silica would have promoted minor uranium redistribution and its accumulation in some fine silica layers outside of the silica rhizoliths.

\section{CONCLUSIONS}

This paper describes and discusses three calcrete-silcrete profiles occurring in distal areas of alluvial-fan systems within the Madrid Basin. The following conclusions can be drawn.

1. The studied calcretes do not show "classic" profiles since they lack nodular, massive, powdery, or hardpan horizons. On the contrary, they consist mostly of calcified root systems developed in the detrital parent material. The mechanisms of carbonate precipitation were mostly driven by the activity of roots and their associated microorganisms, forming thin laminar calcretes.

2. Silcretes formed by replacement in several stages. Early silicification occurred in a pedogenic-vadose environment affecting the detrital parent material, roots, and calcretes, forming an early silcrete (pedogenic silcrete) defined by opaline glaebules and silica rhizoliths. The initial silica accumulations were, in some cases, disrupted by a phase of calcrete development, indicating that some silicification processes were very early indeed. Later on, more general silica replacement of the detrital parent material and calcretes occurred in both phreatic and vadose environments, as respectively indicated by the preservation of the texture of the host rocks (typical of groundwater 
silcretes) and by the characteristic textures of the vadose silcretes seen, e.g., ovoidal opaline accumulations, intraclasts produced by autobrecchification, and vadose silica cements. Calcrete-silcrete intergrades therefore formed under pedogenic-vadose and phreatic conditions.

3. Geochemical features of calcretes and silcretes are inherited from relicts of the parent materials. However, the $\mathrm{Ce}$ anomalies of some silcretes are different from those of the parent materials. That these $\mathrm{Ce}$ anomalies are sometimes positive suggests oxidizing conditions during silcrete formation, possibly due to residual solutions left behind after the main calcretization process.

4. The good correlation between silica and uranium suggests that the latter is located in the silica phases and not in the carbonates. Uranium-bearing silcretes initially acquired the element through the direct silicification of roots that fixed it from organic matter. Subsequent uranium mobilization was due mainly to the aging of opal to quartz. U-bearing siliceous rhizoliths indicate the important role of plants in uranium fixation in surface environments.

5. The location of these integrades at the boundary between the Lower and Intermediate Miocene Units indicates that similar overlappings of pedogenic and phreatic duricrust profiles can be used as a marker of important sedimentary discontinuities in other continental basins.

\section{ACKNOWLEDGMENTS}

The authors are grateful to Laura Tormo, Marta Furió, and Alberto Jorge García of the laboratory of "Non-destructive analytical techniques," Museo Nacional de Ciencias Naturales, for assistance with the CL-SEM-EDS-WDS and Micro-Raman analyses. This work was funded by Projects CGL201127826-CO2-01 and -02 from the Spanish Ministry of Science and Innovation. We would like to thank reviewers Dr. Medard Thiry, Dr. Julia KahmannRobinson, and Dr. Dennis Terry and Associate Editors Dr. Stacy Atchley and Dr. Paul McCarthy for their elaborated and detailed reviews, which greatly improved the manuscript. We also wish to thank James MacEachern for helpful editorial comments.

We thank James Cerne, Adrian Burton, and John B. Southard for assistance with the English manuscript.

Tables 1-3 are available from JSR's Data Archive: http://sepm.org/pages. aspx?pageid $=229$.

\section{REFERENCES}

Aguirre, E., Alberdi, M.T., Jiménez, E., Martín-Escorza, C., Morales, J., Sesé, C., AND SorIA, D., 1982, Torrijos: nueva fauna con Hispanotherium de la cuenca media del Tajo: Acta Geológica Hispánica, v. 1, p. 39-61.

Alonso-Zarza, A.M., 1999, Initial stages of laminar calcrete formation by roots: examples from the Neogene of central Spain: Sedimentary Geology, v. 126, p. 177 191

Alonso-Zarza, A.M., And Jones, B.J., 2007, Root calcrete formation on Quaternary karstic surfaces of Grand Cayman: Geologica Acta, v. 5, p. 77-88.

Alonso-Zarza, A.M., AND Wright, V.P., 2010, Palustrine carbonates, in Alonso-Zarza, A.M., and Tanner, L.H., eds., Carbonates in Continental Settings: Facies, Environments and Processes: Amsterdam, Elsevier, Developments in Sedimentology, v. 61 , p. $225-267$.

Alonso-Zarza, A.M., Armenteros, I., Braga, J.C., Muñoz, A., Pujalte, V., Ramos, E., Aguirre, J., Alonso-Gavilán, G., Arenas, C., Baceta, J.I., Carballeira, J., Calvo, J.P., Corrochano, A., Fornós, J.J., Gónzalez, A., Luzón, A., Martín, J.M., Pardo, G., Payrós, A., Pérez, A., Pomar, L., Rodríguez, J.M., and Villena, J., 2002, Tertiary, in Gibbons, W., and Moreno T., eds., The Geology of Spain: The Geological Society, London, p. 293-334.

Alonso-Zarza, A.M., Calvo, J.P., Silva, P.G., and Torres, T., 2004, Cuenca del Tajo, in Vera, J.A., ed., Geología de España: Madrid, Sociedad Geológica de España and Instituto Geológico y Minero de España, p. 556-563.

Arakel, A.V., Jacobson, G., Salehi, M., And Hill, C.M., 1989, Silicification of calcrete in paleodrainage basins of the Australian arid zone: Australian Journal of Earth Sciences, v. 36, p. 73-89.

Armenteros, I., Bustillo, M.A., And Blanco, J., 1995, Pedogenic and groundwater processes in a closed Miocene basin (northern Spain): Sedimentary Geology, v. 99, p. 17-36.

BaJnóczI, B., AND KovÁcs-KIs, V., 2006, Origin of pedogenic needle-fiber calcite revealed by micromorphology and stable isotope composition: a case study of a Quaternary paleosol from Hungary: Chemie der Erde, v. 66, p. 203-212.
Billard, I., AND Geipel, G., 2008, Luminescence analysis of actinides: instrumentation, applications, quantification, future trends, and quality assurance: Fluorescence, v. 5, p. $465-492$.

Braun, J., Pagel, M., Muller, J., Billong, P., Michard, A., and Guillet, B., 1990, Cerium anomalies in lateritic profiles: Geochimica et Cosmochimica Acta, v. 54, p. 781-795.

Bustillo, M.A., 1982, Aging features in inorganic continental opals: Estudios Geológicos, v. 38, p. 335-344.

Bustillo, M.A., 2010, Silicification of continental carbonates, in Alonso-Zarza, A.M. and Tanner, L.H., eds., Carbonates in Continental Settings: Processes, Facies and Applications: Amsterdam, Elsevier, Developments in Sedimentology, v. 62, p. 153-174

Bustillo, M.A., and Alonso-Zarza, A.M., 2007, Overlapping of pedogenesis and meteoric diagenesis in distal alluvial and shallow lacustrine deposits in the Madrid Miocene Basin, Spain: Sedimentary Geology, v. 198, p. 255-271.

Bustillo, M.A., Perez-Jimenez, J.L., Alonso-Zarza, A.M., And Furio, M., 2012 Moganite in the chalcedony varieties of continental cherts (Miocene, Madrid Basin Spain): Spectroscopy Letters, v. 45, p. 109-113.

Cañaveras, J.C., Sánchez-Moral, S., Calvo, J.P., Hoyos, M., and Ordóñez, S., 1996, Dedolomites associated with karstic features, an example of early dedolomitization in lacustrine sequences from the Tertiary Madrid Basin, Central Spain: Carbonates and Evaporites, v. 11, p. 85-103.

CAPO, R.C., AND CHADWICK, O.A., 1999, Sources of strontium and calcium in desert soil and calcrete: Earth and Planetary Science Letters, v. 170, p. 61-72.

CHENG C, 2010, Optical measurement of environmental uranium using porous silica materials [Dissertation, Degree of Doctor]: Virginia Commonwealth University, Taiwan. http://hdl.handle.net/10156/3074.digarchive.library.vcu.edu

Clayton, C.J., 1986, The chemical environment of flint formation in Upper Cretaceous chalks, in Sieveking, G.G., and Hart, M.B., eds., The Scientific Study of Flint and Chert: Cambridge, U.K., Cambridge University Press, p. 43-54.

Dart, R.C., Barovich, K.M., Chittleborough, D.J., And Hill, S.M., 2007, Calcium in regolith carbonates of central and southern Australia: its source and implications for the global carbon cycle: Palaeogeography, Palaeoclimatology, Palaeoecology, v. 249, $322-334$

Dixon, J.C., And McLaren, S.J., 2009, Duricrust, in Parson, A.J., and Abrahams, A.D., eds., Geomorphology of Desert Environments: Berlin, Springer, p. 123-151.

Dusenkov, S., Vasudey, D., Kapulnik, Y., Gleba, D., Fleisher, D., Ting, K.C., and ENSLEY, B., 1997, Removal of Uranium from water using terrestrial plants: Environmental Science and Technology, v. 31, p. 3468-3474.

EbBs, D.S., Bradi, D.J., and Kochian, L.V., 1998, Role of uranium speciation in the uptake and translocation of uranium by plants: Journal of Experimental Botany, y. 49 , p. $1183-1190$

Elsass, F., DubroeucQ, D., and Thiry, M., 2000, Diagenesis of silica minerals from clay minerals in volcanic soils of Mexico: Clay minerals, v. 35, p. 477-489.

Epstern E, 2001, Silicon in plants: facts vs. concepts: Studies in Plant Science, v. 8 , p. $1-15$

Esteban, M., and Klappa, C.F., 1983, Subaerial exposure environments, in Scholle, P.A., Bebout, D.G., and Moore, C.H., eds., Carbonate Depositional Environments: American Association of Petroleum Geologists, Memoir 33, p. 1-96.

FolK, R., AND PitTMAn, S., 1971, Length-slow chalcedony: a new testament for vanished evaporates: Journal of Sedimentary Petrology, v. 41, p. 1045-1058.

Frost, R.L., AND CEJKA, J., 2009, Raman spectroscopic study of the uranyl phosphate mineral dumontite $\mathrm{Pb}_{2}\left[\left(\mathrm{UO}_{2}\right)_{3} \mathrm{O}_{2}\left(\mathrm{PO}_{4}\right)_{2}\right]$. 5 $\mathrm{H}_{2} \mathrm{O}$ : Journal of Raman Spectroscopy, $\mathrm{v}$. 40 , p. $591-594$

Gile, L.H., Peterson, F.F., and Grossman, R.B., 1965, The K horizon: a master horizon of carbonate accumulation: Soil Science, v. 97, p. 74-82.

Gómez, P., Turrero, M.J., Peña, J., Gimeno, M.J., Crespo, M.T., Gordienko, F.B., Martínez, F., Reyes, E., Rivas, P., And Ivanovich, M., 1996, Procesos de interacción agua-roca y comportamiento del uranio en el sistema granítico de El Berrocal (España): Geogaceta, v. 20, p. 1626-1629.

Gotze, J., Plötze, M., And Habermann, D., 2001, Origin, spectral characteristics and practical applications of the cathodoluminescence $(\mathrm{CL})$ of quartz. A review: Mineralogy and Petrology, v. 71, p. 225-250.

Gromet, L.P., Haskin, L.A., Korotev R.L., and Dymek, R.F., 1984, The "North American shale composite": its compilation, major and trace element characteristics: Geochimica et Cosmochimica Acta, v. 48, p. 2469-2482.

Jaillard, B., GuYon, A., And Maurin, A.F., 1991, Structure and composition of calcified roots and their identification in calcareous soils: Geoderma, v. 50, p. 197 210 .

JoNES, B., 1992, Construction of spar calcite crystals around spores: Journal of Sedimentary Petrology, v. 62, p. 1054-1057

Junco, F., and Calvo, J.P., 1983, Cuenca de Madrid, in Geología de España, Libro Homenaje a J.M. Ríos: Madrid, Instituto Geológico y Minero de España, v. 2, p. 534 542.

Kabata-Pendias, A., and Pendias, H., 2001, Trace elements in soils and plants: Washington, CRC Press, $413 \mathrm{p}$.

Kosir, A., 2004, Microcodium revisited: root calcification products of terrestrial plants on carbonate-rich substrates: Journal of Sedimentary Research, v. 74, p. 845-857.

Kampunzu, A.B., Ringrose, S., Huntsman-Mapila, P., Harris, C., VinK, B.W., and Matheson, W., 2007, Origins and palaeo-environments of Kalahari duricrusts in the Moshaweng dry valleys (Botswana) as detected by major and trace element composition : Journal of African Earth Sciences, v. 48, p. 199-221.

KHALAF, F.I., 1988, Petrography and diagenesis of silcrete from Kuwait, Arabian Gulf: Journal of Sedimentary Petrology, v. 58, p. 1014-1022. 
KNAUth, L.P., 1979, A model for the origin of chert in limestone: Geology, v. 7, p. 274 277.

KnolL, A.H., 1985, Exceptional preservation of photosynthetic organisms in sicilified carbonates and silicified peats: Royal Society of London, Philosophical Transactions B, v. 311, p. 111-122.

Laroche, L., Henner, P., Camilleri, V., Morello, M., and Garnier-Laplace, J., 2005, Root uptake of uranium by a higher plant model (Phaseolus vulgaris), bioavailability from soil solution: Radioprotection, v. 40, p. 33-39.

LiU, S., AND JaIRETH, S., 2011, Exploring for calcrete-hosted uranium deposits in the Paterson region, Western Australia: AusGeo News, v. 103, p. 1-5.

López Olmedo, F., Díaz De Neira, A., Martín Serrano, A., Calvo, J.P., Morales, J., and Peláez-Campomanes, P., 2004, Unidades estratigráficas en el registro sedimentario Neógeno del sector occidental de la Cuenca de Madrid: Sociedad Geológica de España, Revista, v. 17, p. 87-101.

Luna Porres, M.Y., Alarcón Herrera, M.T., Silva Sáenz, M., Rentería Villalobos, M., Rodriguez Villa, M.A., Herrera Peraza, E., Reyes Cortés, M., and Montero CABrera, M.E., 2011, Baccharis salicifolia development in the presence of high concentrations of uranium in the arid environment of San Marcos, Chihuahua: Revista Mexicana de Física, v. 57, p. 40-43.

Lynne, B.Y., Campbell, K.A., Moore, J.N., and Browne, P.R.L., 2005, Diagenesis of 1900-year-old siliceous sinter (opal-A to quartz) at Opal Mound, Roosevelt Ho Springs, Utah, U.S.A.: Sedimentary Geology, v. 179, p. 249-278.

Machette, M.N., 1985, Calcic soils of southwestern United States, in Weide, D.L., ed. Soil and Quaternary Geology of the Southwestern United States: Geological Society of America, Special Paper 203, p. 1-21.

Mack, G.H., AND James, W.C., 1992, Calcic paleosols of the Plio-Pleistocene Camp Rice and Palomas Formations, southern Rio Grande rift, US: Sedimentary Geology, v. 77 , p. $89-109$.

Mack, G.H., James, W.C., AND Monger, H.C., 1993, Classification of paleosols: Geological Society of America, Bulletin, v. 105, p. 129-136.

Maliva, R.G., AND Siever, R., 1989, Nodular chert formation in carbonate rocks Journal of Geology, v. 97, p. 421-433.

Manara, D., And Renker, B., 2003, Raman spectra of stoichiometric and hyperstoichiometric uranium dioxide: Journal of Nuclear Materials, v. 321, p. 233 237.

McCarthy, T.S., And Ellery, W.N., 1995, Sedimentation on the distal reaches of the Okavango Fan, Botswana, and its bearing on calcrete and silcrete (ganister) formation: Journal of Sedimentary Research, v. 65, p. 77-90.

McQueEn, K.G., 2006, Calcrete geochemistry in the Cobar-Girilambone Region, New South Wales: Australia, Cooperative Research Centre for Landscape Environments and Mineral Exploration, Open File Report 200.

Meléndez, A., Alonso-Zarza, A.M., and Sancho, C., 2011, Multi-story calcrete profiles developed during the initial stages of the configuration of the Ebro Basin's exorrheic fluvial network: Geomorphology, v. 134, p. 232-248.

Morse, W.M., and Mackenzie, F.T., 1990, Geochemistry of Sedimentary Carbonates: Amsterdam, Elsevier, Developments in Sedimentology, v. 48, 707 p.

NASH, D.J., AND SHAw P.A., 1998, Silica and carbonate relationships in silcrete-calcrete intergrade duricrusts from the Kalahari of Botswana and Namibia: Journal of African Earth Sciences v. 27, p. 11-25.

Nash, D.J., And Ullyott, J.S., 2007, Silcrete, in Nash, D., and McLaren, S.J. eds. Geochemical Sediments and Landscapes: Oxford U.K., Blackwell, p. 95-143.

Nash D.J., McLaren S.J., and WebB, J.A., 2004, Petrology, geochemistry and environmental significance of silcrete-calcrete intergrade duricrusts at Kang Pan and Tswaane, central Kalahari, Botswana: Earth Surface Processes and Landforms, v. 29 , p. $1559-1582$.

Nettleton, W.D., Olson, C.G., and Wysocki, D.A., 2000, Paleosol classification: problems and solutions: Catena, v. 41, p. 61-92.

Ordóñez, S., Calvo, J.P., García Del Cura, M.A., Alonso-Zarza, A.M., and Hoyos, M., 1991, Sedimentology of sodium sulphate deposits and special clays from the Tertiary Madrid Basin (Spain), in Anadón, P., Cabrera, L., and Kelts, K., eds. Lacustrine Facies Analysis: International Association of Sedimentologists, Special Publication, 13, p. 39-55.

Owen, R.B., Renaut, R.W., Scott, J.J., Jones, B., and Ashley, G.M., 2008, Mineralogy and origin of rhizoliths on the margins of saline, alkaline Lake Bogoria, Kenya Rift Valley: Sedimentary Geology, v. 203, p. 143-163.

PÉReZ-JimÉneZ, J.L., 2010, Sedimentología, silicificaciones y otros procesos diagenéticos en las unidades Intermedia y Superior del Mioceno de la Cuenca de Madrid (zonas NE, NW y W) [Degree of Doctor, Facultad de Geológicas]: Universidad Complutense Madrid, 336 p. ISBN 978-84-694-9538-4.

Piltch, M.S., Gray, P.C., Cooley, J.C., and Manley, M., 2009, Surface-enhanced Raman scattering in insulating materials by artificial plasmon production: application to uranium compounds: Symposium on Correlated Electron Materials: Philosophical Magazine, v. 89, p. 1947-1951

Pointurier, F., AND Marie, O., 2010, Identification of the chemical forms of uranium compounds in micrometer-size particles by means of micro-Raman spectrometry and scanning electron microscope: Spectrochimica Acta, Part B: Atomic Spectroscopy, v. 65 , p. 797-804.
Ramakrishnan, D., and Tiwari, K.C., 1998, REE chemistry of arid zone calcrete profiles, a case study from the Thar Desert, India: Turkish Journal of Earth Sciences, v. 7, p. 97-103.

Retallack, G.J., 1988, Field recognition of paleosols, in Reinhart, J., and Sigleo, W.R., eds., Paleosols and Weathering through Geologic Time: Principles and Applications: Geological Society of America, Special Paper 216, p. 1-20.

Retallack, G.J., 1993, Classification of paleosols: discussion: Geological Society of America, Bulletin, v. 105, p. 1635-1637.

Ringrose, S., Harris, C., Huntsman-Mapila, P., Vink, B.W., Diskins, S., Vanderpost, C., And Matheson, W., 2009, Origins of strandline duricrusts around the Makgadikgadi Pans (Botswana Kalahari) as deduced from their chemical and isotope composition: Sedimentary Geology, v. 219, p. 262-279.

Rodríguez-Aranda, J.P., Calvo, J.P., And Sanz-Montero, M.E., 2002, Lower Miocene gypsum palaeokarst in the Madrid Basin (central Spain): dissolution diagenesis, morphological relicts and karst end-products: Sedimentology, v. 49, p. $1385-1400$

Rossinsky, V., Wanless, H.R., And Swart, P.K., 1992, Penetrative calcretes and their stratigraphic implications: Geology, v. 20, p. 331-334.

Sarsfield, M.J., ANd Helliwell, M., 2004, Extending the chemistry of the uranyl ion: Lewis acid coordination to a U-O oxygen: American Chemical Society, Journal v. 126 , p. $1036-1037$

Schindler, M., Fayek, M., And Hawthorne, F.C., 2010, Uranium-rich opal from the Nopal I uranium deposit, Peña Blanca, Mexico: evidence for the uptake and retardation of radionuclides: Geochimica et Cosmochimica Acta, v. 74, p. 187-202.

Shawky, S., Abdel Geleel, M., And Aly, A., 2005, Sorption of uranium by non-living water hyacinth roots: Journal of Radionalytical and Nuclear Chemistry, v. 265, p. 8184

Siever, R., 1962 , Silica solubility $0^{\circ}-200^{\circ} \mathrm{C}$ and the diagenesis of siliceous sediments: Journal of Geology, v. 70, p. 127-150.

Soll Survey Staff, 1975, Soil Taxonomy, a Basic System of Soil Classification for Making and Interpreting Soil Surveys: U.S. Department of Agriculture, Handbook, $436 \mathrm{p}$.

Sommer, M., Kaczorek, D., Kuzyakov, Y., and Breuer, J., 2006, Silicon pools and fluxes in soils and landscapes, a review: Journal of Plant Nutrion Soil Science, v. 169 p. $310-329$.

Stevens-Kalceff, M.A., Philuips, M.R. Moon, A.R., and Smallwood, A., 1997, Cathodoluminescence microanalysis of natural hydrated amorphous $\mathrm{SiO}_{2}$; opal: Physics and Chemistry of Minerals, v. 24, p. 131-138.

Summerfield, M.A., 1982, Distribution, nature and probable genesis of silcrete in arid and semi-arid Southern Africa, in Yaalon, D.H., ed., Aridic Soils and Geomorphic Processes: Catena Supplement 1, Braunschweig, p. 37-65.

Summerfield, M.A., 1983, Geochemistry of weathering profile silcretes, southern Cape Province, South Africa, in Wilson, R.C.L., ed., Residual Deposits: Surface and Related Weathering Processes and Materials: Geological Society of London, Specia Publication 11, p. 167-178.

ThIRY, M., 1997, Continental silicifications: a review, in Paquet, H., and Clauer, N., eds., Soils and Sediments: Mineralogy and Geochemistry: Berlin, Springer, p. 191221.

Thiry M, And Millot G, 1987, Mineralogical forms of silica and their sequence of formation in silcretes: Journal of Sedimentary Petrology, v. 57, p. 343-352.

Thiry, M., And Milnes, A.R., 1991, Pedogenic and groundwater silcretes at Stuart Creek Opal Field, South Australia: Journal of Sedimentary Petrology, v. 61, p. 111 127.

ThIRY, M. AND RIBET, I., 1999, Groundwater silicification in Paris basin limestones: fabrics, mechanisms, and modeling: Journal of Sedimentary Research, v. 69, p. 171183

Thiry, M., Bertrand-Ayrault, M., and Grisoni, J.C., 1988, Ground-water silicification and leaching in sands: example of Fontainebleau Sand (Oligocene) in the Paris Basin: Geological Society of America, Bulletin, v. 100, p. 1283-1290.

Verrecchia, E.P., AND VerrecchiA, K.E., 1994, Needle-fiber calcite: a critical review and a proposed classification: Journal of Sedimentary Research, v. 64, p. 650 664

WATTS, N.L., 1980, Quaternary pedogenic calcretes from the Kalahari (southern Africa): mineralogy, genesis and diagenesis: Sedimentology, v. 27, p. 661-686.

WRIGHT, V.P., 1986, The role of fungal biomineralization in the formation of early Carboniferous soil fabrics: Sedimentology, v. 33, p. 831-838

Wright, V.P., AND Tucker, M.E., 1991, Calcretes: an introduction, in Wright, V.P., and Tucker, M.E., eds., International Association of Sedimentologits, Reprint Series: Oxford U.K., Blackwell Scientific Publications, p. 1-22.

Wright, V.P., Platt, N.H., Marriot, S.B., and Beck, V.H., 1995, A classification of rhizogenic (root-formed) calcretes, with examples from the Upper Jurassic-Lower Carboniferous of Spain and Upper Cretaceous of southern France: Sedimentary Geology, v. 100, p. 143-158.

Received 15 October 2012; accepted 6 September 2013 